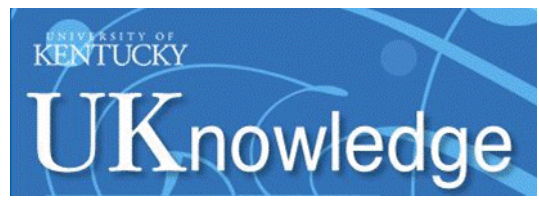

University of Kentucky

UKnowledge

Biosystems and Agricultural Engineering Faculty Publications

\title{
Improving In-Stream Nutrient Routines in Water Quality Models Using Stable Isotope Tracers: A Review and Synthesis
}

\author{
Alexandria K. Jensen \\ University of Kentucky, jensen.alexandria@uky.edu \\ William I. Ford \\ University of Kentucky, bill.ford@uky.edu \\ James F. Fox \\ University of Kentucky, james.fox@uky.edu \\ Admin Husic \\ University of Kentucky, admin.husic@uky.edu
}

Follow this and additional works at: https://uknowledge.uky.edu/bae_facpub

Part of the Biogeochemistry Commons, Bioresource and Agricultural Engineering Commons, and the Water Resource Management Commons

Right click to open a feedback form in a new tab to let us know how this document benefits you.

\section{Repository Citation}

Jensen, Alexandria K.; Ford, William I.; Fox, James F.; and Husic, Admin, "Improving In-Stream Nutrient Routines in Water Quality Models Using Stable Isotope Tracers: A Review and Synthesis" (2018). Biosystems and Agricultural Engineering Faculty Publications. 222.

https://uknowledge.uky.edu/bae_facpub/222

This Article is brought to you for free and open access by the Biosystems and Agricultural Engineering at UKnowledge. It has been accepted for inclusion in Biosystems and Agricultural Engineering Faculty Publications by an authorized administrator of UKnowledge. For more information, please contact UKnowledge@lsv.uky.edu. 


\section{Improving In-Stream Nutrient Routines in Water Quality Models Using Stable Isotope Tracers: A Review and Synthesis}

\section{Digital Object Identifier (DOI)}

https://doi.org/10.13031/trans.12545

\section{Notes/Citation Information}

Published in Transactions of the ASABE, v. 61, issue 1, p. 139-157.

(C) 2018 American Society of Agricultural and Biological Engineers

The copyright holder has granted the permission for posting the article here. 


\section{IMPROVING IN-STREAM NUTRIENT ROUTINES IN WATER QUALITY MODELS USING STABLE ISOTOPE TRACERS: A REVIEW AND SYNTHESIS}

\author{
A. Jensen, W. Ford, J. Fox, A. Husic
}

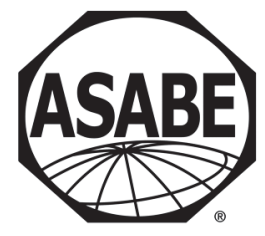

Invited Review

\begin{abstract}
Water quality models serve as an economically feasible alternative to quantify fluxes of nutrient pollution and to simulate effective mitigation strategies; however, their applicability is often questioned due to broad uncertainties in model structure and parameterization, leading to uncertain outputs. We argue that reduction of uncertainty is partially achieved by integrating stable isotope data streams within the water quality model architecture. This article outlines the use of stable isotopes as a response variable within water quality models to improve the model boundary conditions associated with nutrient source provenance, constrain model parameterization, and elucidate shortcomings in the model structure. To assist researchers in future modeling efforts, we provide an overview of stable isotope theory; review isotopic signatures and applications for relevant carbon, nitrogen, and phosphorus pools; identify biotic and abiotic processes that impact isotope transfer between pools; review existing models that have incorporated stable isotope signatures; and highlight recommendations based on synthesis of existing knowledge. Broadly, we find existing applications that use isotopes have high efficacy for reducing water quality model uncertainty. We make recommendations toward the future use of sediment stable isotope signatures, given their integrative capacity and practical analytical process. We also detail a method to incorporate stable isotopes into multi-objective modeling frameworks. Finally, we encourage watershed modelers to work closely with isotope geochemists to ensure proper integration of stable isotopes into in-stream nutrient fate and transport routines in water quality models.
\end{abstract}

Keywords. Isotopes, Nutrients, Uncertainty analysis, Water quality modeling, Watershed.

$\mathrm{D}$ eterministic water quality models provide an economically feasible approach to quantify fluxes and transformations of nutrients and for scenario analysis of dynamic management, land use, and climate conditions. Nevertheless, the reliability of such models to assist with management decisions is questioned due to compounding uncertainties regarding instream transformation rates of contaminants (Beven, 2006; Rode et al., 2010; Robson, 2014; Yen et al., 2014; Wellen et al., 2015; Han and Zheng, 2016). It is the general sentiment in the hydrology and water quality community that researchers need to reduce uncertainty within water quality models. In this article, we work toward this goal by providing a review and synthesis of how stable isotope tracers can reduce uncertainty in these applications.

High uncertainty within water quality modeling is likely an artifact of the historical development of water quality models and continued advancements in perceptual understanding of fluvial biogeochemistry. Following a historical

Submitted for review in July 2017 as manuscript number NRES 12545; approved for publication as an Invited Review by the Natural Resources \& Environmental Systems Community of ASABE in October 2017.

The authors are Alexandria Jensen, Graduate Assistant, and William Ford, Assistant Professor, Department of Biosystems and Agricultural Engineering, and James Fox, Professor, and Admin Husic, Graduate Assistant, Department of Civil Engineering, University of Kentucky, Lexington, Kentucky. Corresponding author: William Ford, University of Kentucky, 1398 Nicholasville Rd., Lexington, KY 40546-0276; phone: 859-218-4368; e-mail: bill.ford@uky.edu. period that saw the development of hydrologic and biogeochemical functions from data collected at the hillslope-plot and stream-reach scales in the early 1970s and 1980s, watershed water quality modeling saw rapid advancement via computational capabilities in the 1990s and 2000s to address growing environmental issues related to nutrients (e.g., estuary seasonal hypoxia). Computational advancement allowed several modeling characteristics to take shape, including the ability to inexpensively incorporate spatially explicit data, perform computations at a different resolution or environment than originally envisioned, and couple water, particulate, and dissolved phases within single numerical model formulations. However, the computational advancement of water quality models has not necessarily negated the conceptual representation of in-stream physics and biogeochemistry. For example, conceptual models have been shown to be quite powerful for understanding fluxes from watersheds (Ford et al., 2017). However, new monitoring and measurement capabilities have shown researchers that coupled physio-biochemical processes may vary from the original hydrologic and biogeochemical functions in models. Furthermore, computational advancements have shifted parameterization of models away from inputs and parameters consistent with their original scale of observation and have produced numerous likely inputs and parameter sets within modeling frameworks (e.g., equifinality, as described below). As a result, computational abilities have outweighed the modeler's ability to constrain input and parameter values 
and have promoted large posterior solution spaces, resulting in high uncertainty. Such uncertainty should be accounted for when reporting and analyzing the results of water quality models.

Given the need to constrain input and parameter values and prevent erroneous model parameterization, innovative data streams should be incorporated into water quality models. Integration of stable isotopes for carbon (C), nitrogen $(\mathrm{N})$, and phosphorus (P) compounds within the model architecture provides one such measurement tool to assist with model uncertainty reduction. This assertion follows recent successes in using water isotope measurements to help parameterize model boundary conditions, reduce model uncertainty due to equifinality, and improve numerical representation of processes within hydrologic model structure (Seibert and McDonnell, 2002; McGuire and McDonnell, 2007; McDonnell and Beven, 2014; Windhorst et al., 2014; Soulsby et al., 2015; Yamanaka and Ma, 2017). In this light, this review article synthesizes the utility of stable isotopes within water quality models to reduce the uncertainty contributed by overparameterization in numerical model estimates, given the ability of stable isotopes to be measured with relatively high precision and accuracy. Our focus is on in-stream biogeochemical modeling of macronutrients, namely $\mathrm{C}, \mathrm{N}$, and $\mathrm{P}$, but at the same time it is well-realized that accurate representation of water and solids (i.e., sediment) within streams is a precursor to predicting $\mathrm{C}, \mathrm{N}$, and $P$ fluxes and transformations.

We show recent literature evidence that coupling stable isotopes within watershed water quality modeling helps with improving the data inputs associated with: (1) providing boundary conditions of the models, (2) constraining model parameterization, and (3) elucidating improvements needed within the conceptual and numerical representation of processes, i.e., the model structure. The efficacy of stable isotopes for this uncertainty reduction goal is noteworthy, given that recent attention on watershed water quality modeling uncertainty has highlighted these same inaccuracies (i.e., problems with precision and accuracy of input and calibration measurements, uncertainty in parameter specification, and the problem of inaccurate model structure) as three major sources of uncertainty within models (Guzman et al., 2015).

\section{Providing Boundary Conditions}

Boundary condition refers to the source contributions of $\mathrm{C}, \mathrm{N}$, and $\mathrm{P}$ phases that need to be considered within watershed water quality modeling. For example, within a nutrient focused model, the boundary condition inputs refer to the spectrum of potential nutrient inputs, such as $\mathrm{N}$ and $\mathrm{P}$ from agricultural and urban sources (Xue et al., 2009; Young et al., 2009; Kendall et al., 2010). As another example, within a sediment $\mathrm{C}$ focused model, the boundary condition inputs refer to the spectrum of potential sediment $\mathrm{C}$ inputs, such as inorganic $\mathrm{C}$, terrestrial particulate $\mathrm{C}$, and autochthonous particulate C (Fox and Ford, 2016; Husic et al., 2017a). The use of stable $\mathrm{C}, \mathrm{N}$, and $\mathrm{P}$-bound isotopes to elucidate the boundary condition inputs within the fabric of watershed water quality modeling is perhaps the most obvious coupling of isotopes with the models, given the widely used data-driven unmixing analysis for apportioning source contributions of both dissolved and particulate phases. Source apportionment has existed as a standalone method; therefore, coupling this method to assist with boundary conditions within water quality models seems natural. For these reasons, several studies have used stable isotopes to assist with boundary conditions within numerical models (Hong et al., 2014; Sebestyen et al., 2014; Xue et al., 2014; Fox and Martin, 2014; Ford and Fox, 2015; Husic et al., 2017b).

\section{Constraining Model Parameterization}

Constraining parameter uncertainty is another prominent problem with in-stream models, especially as the level of model complexity via coupling of processes and phases (i.e., dissolved, particulate, water) increases. For such models, the broad range of parameters leads to large posterior solution spaces for fluxes and transformations. Parameter specification uncertainty is robustly reflected by the concept of equifinality, which refers to the potential for a posterior solution space of acceptable calibrations to be met by multiple parameterizations, or realizations (Beven, 2006; Adiyanti et al., 2016). The Generalized Likelihood Uncertainty Estimation (GLUE) framework provides a means to quantify equifinality and is applied using Monte Carlo-based realizations of a global parameter space and evaluation of the subsequent solutions against measured data to create a posterior solution space (Beven and Binley, 1992; Dean et al., 2009; Jin et al., 2010; Gong et al., 2011; Shen et al., 2012; Ford and Fox, 2017). The acceptance into such a solution space depends on evaluation of measured and modeled data using statistical metrics such as Nash-Sutcliffe efficiency, percent bias, and ratio of the root mean square error to the standard deviation of measured data, e.g., Moriasi et al. (2007). While we commend the excellent work of researchers in quantifying this uncertainty, it has been shown that stable isotopes may also be coupled with water quality models to further reduce such uncertainty (Adiyanti et al., 2016; Ford et al., 2017). In many ways, elucidation of parameterization via stable isotopes within watershed water quality modeling is another highly conceivable method, given the long history of stable isotopes to elucidate reactions (Sharp, 2007). Essentially, stables isotope mass balances that couple biogeochemical reactions within their structure may be added to the elemental mass balances of water quality models, as described in the "Overview of Stable Isotopes" section. These added equations are often accompanied with few new unknowns or insensitive unknowns; therefore, a stable isotope data stream may assist with model parameterization. For these reasons, several studies have used stable isotopes to help with parameterizing water quality models (Tobias and Böhlke, 2011; Van Engeland et al., 2012; Hong et al., 2014; Fox and Martin, 2014; Ford and Fox, 2015; Adiyanti et al., 2016; Ford et al., 2017).

\section{Elucidating Model Improvements}

Elucidating improvements in model structure reflects a third opportunity where stable isotopes may assist with advancing research. As the complexity of nutrient cycling continues to unravel through contemporary measurement techniques, it is recognized that numerical model error can be associated with epistemic uncertainties. Regarding epistemic uncertainty, model structure errors may stem from 
simplified conceptual models, the equations and algorithms used to reflect that conceptualization, and instabilities of the numerical scheme (Borah and Bera, 2003; Guzman et al., 2015). Recent critiques of water quality models have pointed to a need for improving in-stream biogeochemical simulations (Rode et al., 2010; Robson, 2014; Wellen et al., 2015). As an example, advanced deterministic models that reflect in-stream $\mathrm{C}$ and nutrient fate and transport (e.g., AQUATOX, QUAL2K, and WASP) conceptualize the benthos as a two-layer system (1 $\mathrm{mm}$ aerobic and $10 \mathrm{~cm}$ anaerobic) in which all particulate organic matter is contained in the anaerobic layer and is not subjected to erosion-deposition dynamics (Di Toro, 2001; Wool et al., 2006; Chapra et al., 2008; Park et al., 2008). This conceptualization was wellvalidated for large, slow-moving waterbodies; however, for turbulent low-order and low-gradient streams, recent research has highlighted the importance of a dynamic 5 to $10 \mathrm{~mm}$ aerobic sediment layer (i.e., the surficial fine-grained laminae) that controls the seasonality of benthic $\mathrm{C}$ and $\mathrm{N}$ dynamics (Droppo et al., 2001; Walling et al., 2006; Russo and Fox, 2012; Ford and Fox, 2014, 2015, 2017; Fox et al., 2014). As models become more robust, unique tools and approaches are needed that rigorously test our conceptualization of in-stream fate and transport. Stable isotopes coupled within water quality modeling may be used through iterations to enhance or test the validity of the model structure (Tobias and Böhlke, 2011; Hong et al., 2014; Sebestyen et al., 2014; Ford et al., 2017).

This review explains the utility of stable isotopes in improving existing water quality model predictions and reducing uncertainty by improving in-stream nutrient fate and transport routines, specifically by (1) providing boundary conditions of the models, (2) constraining model parameterization, and (3) elucidating improvements needed within the model structure. To support the use of stable isotopes for these goals within water quality models, we provide a sequential and comprehensive review of stable isotopes within the fabric of water quality models. First, we define and explain stable isotope theory for modeling-focused researchers who have had minimal exposure to isotope signatures. Second, we describe the pools, measurements, and applications of stable isotope signatures related to $\mathrm{C}, \mathrm{N}$, and $\mathrm{P}$ cycles in streams. Third, we describe the ability of the isotopes to elucidate sources and transformations so that modelers can understand the breadth of possibilities of where the isotopes are applicable in the stream environment. Fourth, we review watershed water quality modeling studies that have coupled stable isotopes and show how these studies have used the isotopes to reduce uncertainty associated with (1) providing boundary conditions of the models, (2) constraining model parameterization, and (3) elucidating improvements needed within the model structure. Fifth, we provide recommendations to watershed water quality modelers for coupling isotopes into the fabric of the modeling architecture.

\section{OVERVIEW OF STABLE ISOTOPES}

Stable isotopes of a given element have identical chemical properties except for a difference in atomic mass, which is caused by the variable number of neutrons in the nucleus. Carbon, nitrogen, oxygen, and hydrogen all have heavy and light stable isotopes, and the relative abundance of the heavy isotope is measured with high precision using isotope ratio mass spectrometry. The relative abundance of heavy to light isotopes for different oxidation states of an element (e.g., ammonium, nitrate, nitrite) is indicated by the widely used delta $(\delta)$ notation. In the determination of isotopic ratios, the relative differences between a sample and a reference standard may be ascertained with high precision. The delta notation $(\delta)$ was developed by McKinney et al. (1950) to report stable isotope data and is generically defined in equations 1 and 2:

$$
\delta=\left(\frac{R_{\text {smpl }}-R_{\text {std }}}{R_{\text {std }}}\right) \times 1000
$$

where $R$ is the ratio of the abundance of the heavy to light isotopes, $s m p l$ is the sample, and $s t d$ is the reference standard that has a known isotope ratio. $R$ is defined explicitly as:

$$
R=\frac{\left[{ }^{m} X\right]}{\left[{ }^{n} X\right]}
$$

where ${ }^{m} X$ is the heavy isotope, and ${ }^{n} X$ is the light isotope.

The unit of measurement for $\delta$ values is reported in per mil or parts per thousand, represented as \%o, which reflects the relatively low abundance of heavy isotopes in the natural environment. A positive $\delta$ value indicates that the ratio of heavy to light isotopes is greater in the sample than in the standard, and vice versa for a negative $\delta$ value.

Stable isotopes are particularly effective for fingerprinting sources and quantifying rates of biogeochemical transformations due to the preferential use of lighter isotopes in a process termed isotope fractionation. Fractionation is characterized by either equilibrium or kinetic isotope effects (Sharp, 2007). In equilibrium isotope-exchange reactions, the forward and backward reaction rates of any single isotope are equal. Kinetic isotope effects cause isotope fractionation to happen when the system is not in isotopic equilibrium and the forward and backward reaction rates are not equal. In kinetic isotope fractionation, the reaction rates are factors of the isotope masses and their vibrational energy; bonds between the light isotopes break more easily than the heavy isotopes, which have stiffer bonds. This results in the preferential use of lighter isotopes during processes because less energy is required to break the lighter bonds. Fractionation processes that are not metabolically driven or kinetically controlled are associated with either an isotope fractionation factor $(\alpha)$ or an enrichment factor $(\varepsilon)$, which is determined either analytically or experimentally. These values are directly related to one another through equations 3,4 , and 5 :

$$
\alpha_{A-B}=\frac{R_{A}}{R_{B}}
$$

where $\alpha_{A-B}$ is the partitioning of stable isotopes between two substances $A$ and $B$ (fig. 1), and $R$ is the ratio of heavy to light isotopes, as described by equation 1 , calculated for each substance. This equation is expressed as: 


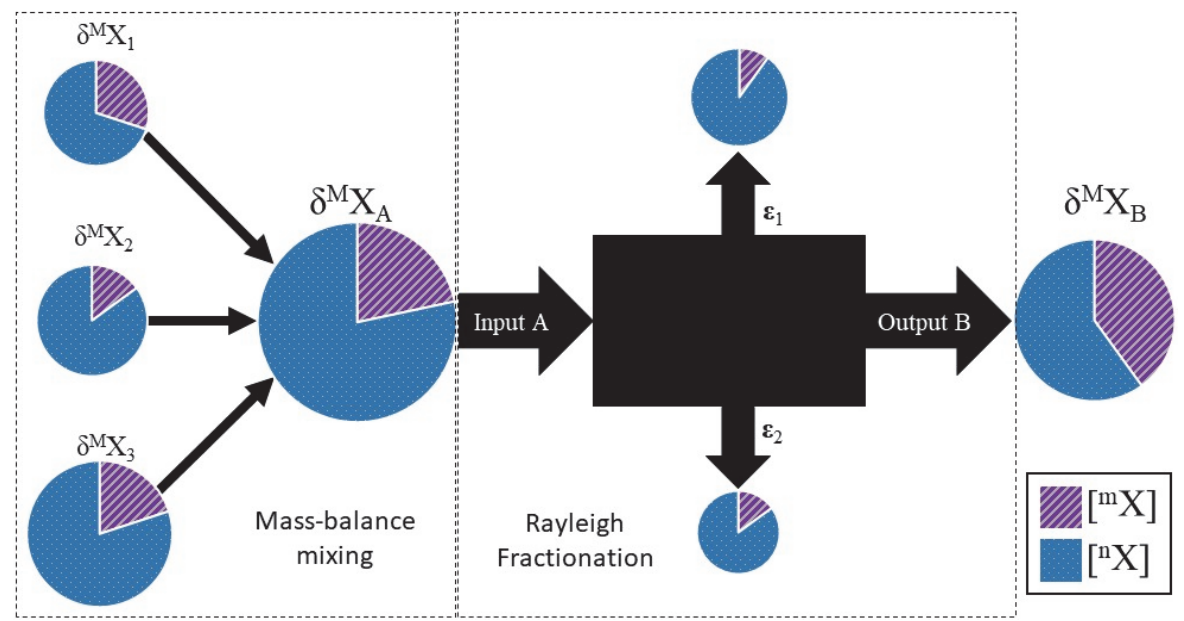

Figure 1. Definition of stable isotope signatures impacted by mass balance mixing of source inputs (left box) and preferential use of lighter isotopes via Rayleigh fractionation during biochemical processes (right box). Element pool compositions are indicated by the heavy $\left({ }^{m} X\right)$ and light $\left({ }^{n} X\right)$ isotope ratios in the pie charts, and the size of the pie chart reflects the total mass of a substance (e.g., substance $A$ is larger than substance $B$ ). Mathematical expressions accounting for these processes are described using the Rayleigh-based mass balance formulation in equation 8.

$$
\alpha_{A-B}=\frac{1000+\delta_{A}}{1000+\delta_{B}}
$$

where $\delta$ is the relative abundance, as described by equation 2, calculated for each substance. The fractionation factor $(\alpha)$ is then related to the enrichment factor $(\varepsilon)$ as:

$$
\varepsilon=(\alpha-1) \times 1000
$$

Using the $\delta$ values and fractional contributions of known sources coupled with the $\varepsilon$ values and rates of reactions, the resulting value of a product is estimated. Namely, the famous Rayleigh formulation (Kendall and Caldwell, 1998) shown in equation 6 is used and coupled to isotope mass balance considerations in separation processes in which a product is removed from a reactant. The Rayleigh equation is used to describe isotopic fractionation processes under the following assumptions: (1) in a mixed system, material is continuously removed that contains molecules of at least two isotopic species (e.g., water with ${ }^{18} \mathrm{O}$ and ${ }^{16} \mathrm{O}$ ), (2) the fractionation associated with the removal process at any instant may be described by the fractionation factor and the enrichment factor, and (3) the fractionation factor and enrichment factor remain constant during the process (Kendall and Caldwell, 1998). The Rayleigh equation may be described as:

$$
\delta^{M} X_{B}=\delta^{M} X_{A}-\varepsilon_{r x n} \ln \left(f_{B-A}\right)
$$

where $M$ is the atomic mass of the isotope, $X$ is the isotope, $A$ and $B$ are the two substances, $r x n$ is the reaction process or pathway of removal, and $f$ is the fraction remaining after the process occurs. Application of this equation becomes invalid under transient kinetic fractionation, which occurs when the reactions leading to fractionation do not follow first-order kinetics (Maggi and Riley, 2009). In general, this limitation may be assumed to have minor impact for nutrient-rich systems and would not be rate-limiting in terms of the lack of availability of the lighter isotope during removal.

Equation 6 is a suitable general definition of the enrichment process, but it may be expanded to accurately represent the dynamics of the system. Multiple inputs across a specified control volume will result in a mixing of sources, as shown in figure 1 (left box). To more accurately represent the upstream conditions, $\delta^{M} X_{A}$ may be broken into a summation incorporating the weighted average of each of the unique source inputs (e.g., the three-source mixing example in fig. 1) as:

$$
\delta^{M} X_{A}=\sum_{l=1}^{k} \delta^{M} X_{l}\left(W_{l}\right)
$$

where $l$ is the source identifier, $k$ is total number of sources, and $W_{l}$ is the fraction of element $X$ from source $l$. Furthering this concept of multiple factors influencing the overall $\delta^{M} X$ value, figure 1 (right box) provides a generic definition of the processes of isotope fractionation to impact stream isotope signatures in a generic stream reach with a generic isotope tracer. Prior to entering the stream at input $A$, there is an abundance of the light isotope in contrast to the heavy isotope. As the substance flows through the stream channel, different biogeochemical processes (e.g., $\varepsilon_{1}$ and $\varepsilon_{2}$ ) occur that preferentially use the lighter isotope in contrast to the heavier isotope. These reactions impact the mass and isotope composition of the outputs depending on the magnitude of the process and the preference for the lighter isotope. As shown in output $B$ of figure 1, the size of the substance pool decreases and the ratio of heavy to light isotopes increases relative to input $A$ because of the fractionation processes $\left(\varepsilon_{1}\right.$ and $\left.\varepsilon_{2}\right)$. The influence of the different biogeochemical processes and fractionation factors may be reflected in the general expression of equation 6 as:

$$
\delta^{M} X_{B}=\delta^{M} X_{A}-\sum_{o=1}^{p} \varepsilon_{o} \ln \left(f_{o}\right)
$$

where $o$ is the enrichment factor identifier, and $p$ is total number of fractionation processes.

We may represent the isotope source mixing and fraction- 
ation processes dynamically by discretizing the system spatially and temporally. Merging equations 7 and 8 and assuming constant enrichment factors through time and space, we can use the following finite difference approximation for the stable isotope mass balance:

$$
\delta^{M} X_{B i}{ }^{j}=\sum_{l=1}^{k} \delta^{M} X_{i, l}{ }^{j}\left(W_{i, l}{ }^{j}\right)-\sum_{o=1}^{p} \varepsilon_{o} \ln \left(f_{i, o}{ }^{j}\right)
$$

where $i$ is the timestep identifier, and $j$ is the reach identifier. In this definition, the mass of an element remaining in a stream reach from a previous timestep is considered a source and is accounted for in the first summation term.

\section{OVERVIEW OF C, N, AND P STABLE ISOTOPES IN FLUVIAL SYSTEMS}

Isotope signatures have been widely used by environmental and water resource engineers as well as aquatic biogeochemists to study $\mathrm{C}, \mathrm{N}$, and $\mathrm{P}$ dynamics in streams and rivers (table 1). This section describes (1) the pools of $\mathrm{C}, \mathrm{N}$, and $\mathrm{P}$ species, (2) the isotope signatures used to study $\mathrm{C}, \mathrm{N}$, and $\mathrm{P}$ dynamics in streams, and (3) some of the applications for which isotopes have been commonly used.

\section{CARBON}

Primary forms of $\mathrm{C}$ in fluvial ecosystems include dissolved organic C (DOC), particulate organic C (POC), and dissolved inorganic $\mathrm{C}$ (DIC) in the form of dissolved carbonates (Hope et al., 1994). Briefly, DIC occurs as $\mathrm{CO}_{3}{ }^{2-}$, $\mathrm{HCO}_{3}{ }^{-}, \mathrm{H}_{2} \mathrm{CO}_{3}$, and dissolved $\mathrm{CO}_{2}$, collectively forming the carbonate system. POC and DOC are C from organic compounds, including terrestrial leaf litter and detritus, autochthonous biomass, and biota. POC is distinguished from DOC by size classification, i.e., the solid matter that is retained on a $0.45 \mu \mathrm{m}$ filter. For the purposes of this article, POC is further classified as fine POC (silt and clay sized particles, or $d<53 \mu \mathrm{m}$ ) and coarse POC (sand, cobble, or gravel sized particles, or $d>53 \mu \mathrm{m})$. DOC is primarily composed of fulvic and humic acids leached from upland soils and benthic organic matter.

Carbon exists in three isotopic forms, with ${ }^{12} \mathrm{C}$ and ${ }^{13} \mathrm{C}$ as stable isotopes and ${ }^{14} \mathrm{C}$ as the radioactive isotope; only the stable forms are considered here. Carbon isotopic signatures are readily measured for all forms using well-accepted methods and are reported as the relative abundance of ${ }^{13} \mathrm{C}$ to ${ }^{12} \mathrm{C}$ for a sample as:

$$
\begin{aligned}
& \delta^{13} \mathrm{C}_{\text {sample }}= \\
& \left(\frac{\left({ }^{13} \mathrm{C} /{ }^{12} \mathrm{C}\right)_{\text {sample }}-\left({ }^{13} \mathrm{C} /{ }^{12} \mathrm{C}\right)_{\mathrm{VPBD}}}{\left({ }^{13} \mathrm{C} /{ }^{12} \mathrm{C}\right)_{\mathrm{VPBD}}}\right) \times 1000
\end{aligned}
$$

where VPDB is the reference standard Vienna Pee Dee Belemnite.

Well accepted methods exist to measure $\delta^{13} \mathrm{C}$ of all three pools: $\delta^{13} \mathrm{C}_{\text {DIC }}$ has been used as a tracer of $\mathrm{C}$ pathways, biotic uptake and regeneration, and atmospheric exchange rates (e.g., Doctor et al., 2008; Throckmorton et al., 2015); $\delta^{13} \mathrm{C}_{\mathrm{DOC}}$ has been used in a wide variety of applications, including quantitative apportionment of allochthonous versus autochthonous organic matter (Grey et al., 2001; Zah et al., 2001; Kritzberg et al., 2004; Doi, 2009; Lau et al., 2009), provision of information on trophic linkages (Rosenfeld and Roff, 1992; Zah et al., 2001; Doi, 2009; Lau et al., 2009), and characterization of nutrient sources and terrestrial inputs (Thornton and McManus, 1994; Palmer et al., 2001; Hood et al., 2005); $\delta^{13} \mathrm{C}_{\mathrm{FPOC}}$ has commonly been used as a fingerprint for sediment source apportionment (Papanicolaou et al., 2003; Fox and Papanicolaou, 2007; Fox, 2009; Jacinthe et al., 2009; Imberger et al., 2014), as a metric to partition terrestrial versus allochthonous organic matter contributions in suspended loads (e.g., Kendall et al., 2001), and as a metric to provide insight into organic matter quality (Ford et al., 2015a; Fox and Ford, 2016; Lu et al., 2016).

\section{NitroGEN}

Prevailing pools of $\mathrm{N}$ in fluvial ecosystems include dissolved organic $\mathrm{N}(\mathrm{DON})$, dissolved inorganic $\mathrm{N}$ (DIN), and particulate organic $\mathrm{N}(\mathrm{PON})$. The distinctions between DOC and POC also apply to DON and PON. Regarding DIN, nitrate $\left(\mathrm{NO}_{3}{ }^{-}\right)$and ammonium $\left(\mathrm{NH}_{4}{ }^{+}\right)$are of the largest pools; however, nitrite $\left(\mathrm{NO}_{2}{ }^{-}\right)$may often also exist in measurable quantities in the water column. Nevertheless, $\mathrm{NO}_{2}{ }^{-}$is an intermediate step in the nitrification process and, in general, is rapidly converted to nitrate (Kendall and Caldwell, 1998). Nitrogen has two stable isotopes $\left({ }^{14} \mathrm{~N}\right.$ and $\left.{ }^{15} \mathrm{~N}\right)$; hence, stable isotope signa-

\begin{tabular}{|c|c|c|c|c|}
\hline Pool & $\begin{array}{c}\mathrm{C} \\
\left(\delta^{13} \mathrm{C}\right)\end{array}$ & $\begin{array}{c}\mathrm{N} \\
\left(\delta^{15} \mathrm{~N}\right)\end{array}$ & $\begin{array}{c}\mathrm{O} \\
\left(\delta^{18} \mathrm{O}\right)\end{array}$ & References \\
\hline \multicolumn{5}{|l|}{ Carbon } \\
\hline $\begin{array}{l}\text { Dissolved inorganic carbon }\left(\mathrm{H}_{2} \mathrm{CO}_{3} \text {, }\right. \\
\left.\mathrm{HCO}_{3}, \mathrm{CO}_{3} \text {, and } \mathrm{CO}_{2}\right)\end{array}$ & $\mathrm{X}$ & - & - & Doctor et al., 2008; Gammons et al., 2011; Rounick et al., 1982 \\
\hline Particulate organic carbon (POC) & $\mathrm{X}$ & - & - & Zah et al., 2001; Kendall et al., 2001; Kao and Liu, 2000 \\
\hline Dissolved organic carbon (DOC) & $\mathrm{X}$ & - & - & Palmer et al., 2001; Schiff et al., 1990; Raymond et al., 2007 \\
\hline \multicolumn{5}{|l|}{ Nitrogen } \\
\hline Nitrate $\left(\mathrm{NO}_{3}{ }^{-}\right)$and nitrite $\left(\mathrm{NO}_{2}^{-}\right)$ & - & $\mathrm{X}$ & $\mathrm{X}$ & Fukada et al., 2003; Pardo et al., 2004; Chang et al., 2002; Kaown et al., 2009 \\
\hline Ammonium $\left(\mathrm{NH}_{4}^{+}\right)$ & - & $\mathrm{X}$ & - & Webster and Heymsfield, 2003; Peterson et al., 2001; Ashkenas et al., 2004 \\
\hline Particulate organic nitrogen $(\mathrm{PON})$ & - & $\mathrm{X}$ & - & Kendall et al., 2001; Angradi, 1994; Sarà et al., 2004 \\
\hline \multicolumn{5}{|l|}{ Phosphorus } \\
\hline Dissolved reactive phosphate $\left(\mathrm{PO}_{4}{ }^{3-}\right)$ & - & - & $\mathrm{X}$ & Young et al., 2009; Elsbury et al., 2009; Davies et al., 2014 \\
\hline Soil and sediment extractable phosphate & - & - & $\mathrm{X}$ & Tamburini et al., 2012, 2014; Pistocchi et al., 2017 \\
\hline
\end{tabular}
tures reflect the relative abundance of ${ }^{15} \mathrm{~N} /{ }^{14} \mathrm{~N}$ as:

Table 1. Measurable $\mathrm{C}, \mathrm{N}$, and $\mathrm{O}$ isotope signatures and their relevance to significant $\mathrm{C}, \mathrm{N}$, and $\mathrm{P}$ phases in stream and riverine environments. 


$$
\begin{aligned}
& \delta^{15} \mathrm{~N}_{\text {sample }}= \\
& \left(\frac{\left({ }^{15} \mathrm{~N} /{ }^{14} \mathrm{~N}\right)_{\text {sample }}-\left({ }^{15} \mathrm{~N} /{ }^{14} \mathrm{~N}\right)_{\text {ref }}}{\left({ }^{15} \mathrm{~N} /{ }^{14} \mathrm{~N}\right) \text { ref }}\right) \times 1000
\end{aligned}
$$

where $r e f$ is derived from atmospheric $\mathrm{N}_{2}$ or solid reference samples from NIST and IAEA (Sharp, 2007). In addition, dual-isotope approaches are commonly used for nitrate source apportionment studies. Stable oxygen isotope signatures of nitrate reflect the relative abundance of ${ }^{18} \mathrm{O}$ to ${ }^{16} \mathrm{O}$ as:

$$
\begin{aligned}
& \delta^{18} \mathrm{O}_{\mathrm{NO} 3}= \\
& \left(\frac{\left({ }^{18} \mathrm{O} /{ }^{16} \mathrm{O}\right)_{\text {NO3 }}-\left({ }^{18} \mathrm{O} /{ }^{16} \mathrm{O}\right)_{\text {VSMOW }}}{\left({ }^{18} \mathrm{O} /{ }^{16} \mathrm{O}\right)_{\text {VSMOW }}}\right) \times 1000
\end{aligned}
$$

where VSMOW is the international standard Vienna Standard Mean Ocean Water (Tamburini et al., 2014).

As shown in table $1, \mathrm{~N}$ isotope signatures are commonly measured for DIN, PON, and DON. Similar to C, $\delta^{15} \mathrm{~N}$ of PON and DON has been used to separate allochthonous and autochthonous pathways in trophic interactions (Rounick and Winterbourn, 1986), distinguish aquatic and terrestrial organic matter sources (Finlay, 2001; Kendall et al., 2001; England and Rosemond, 2004), elucidate denitrification and plant uptake rates (Clément et al., 2003), and perform sediment source apportionment (Fox and Papanicolaou, 2007; Fox, 2009). Measurements of DIN have included injection and ambient measures to assess sources and biogeochemical transformations. Enriched ${ }^{15} \mathrm{~N}$ tracer applications of DIN have been widely used since the 1960 s for monitoring of specific product $\left({ }^{15} \mathrm{~N}\right)$ input to streams (Webster and Heymsfield, 2003; Ashkenas et al., 2004; Böhlke et al., 2004) and have been useful in estimating biological uptake and regeneration rates in streams. Ambient measures of isotope signatures of ammonium, nitrate, and nitrite are commonly used in streams and rivers for source identification and for assessing in situ rates of in-stream transformations. Ammonium isotope applications have incorporated $\delta^{15} \mathrm{~N}$ measurements to effectively indicate the amount of exchangeable ammonium in soils (Bremner and Keeney, 1966), determine the algal assimilation of ammonium (Cifuentes et al., 1989), and determine the dissolved ammonium level at natural abundance conditions from estuarine waters (Velinsky et al., 1989). Ambient dual-isotope approaches for nitrate are commonly employed and have been reviewed extensively elsewhere (Chang et al., 2002; Fukada et al., 2003; Wankel et al., 2006; Xue et al., 2009). The use of ${ }^{18} \mathrm{O}$ of nitrate coupled with ${ }^{15} \mathrm{~N}$ of nitrate is effective for linking the prior value to the entire $\mathrm{N}$ cycle, which may be biased due to kinetic isotope fractionation or source mixing (Komor, 1997; Aravena and Robertson, 1998; Widory et al., 2004; Seiler, 2005).

\section{Phosphorus}

Analogous to $\mathrm{C}$ and $\mathrm{N}$, primary pools of $\mathrm{P}$ include permutations of organic, inorganic, particulate, and dissolved phases and interactions between those phases (fig. 4a; Withers and Jarvie, 2008). Most commonly studied pools in stream ecosystems include dissolved inorganic (or reactive) $\mathrm{P}$ (DRP) and sediment exchangeable particulate inorganic $\mathrm{P}$ (PIP), which includes mineral precipitates and adsorption to sediment surfaces (Withers and Jarvie, 2008). These pools have likely received attention due to their relatively high abundance in urban and agroecosystems and their ability to independently promote downstream eutrophication. Nevertheless, the fluvial P cycle is also affected by particulate organic $\mathrm{P}$ and dissolved organic $\mathrm{P}$.

Isotope tracing of $\mathrm{P}$ source, fate, and transport is an emerging technique in freshwater ecosystems that has been successfully applied over the past decade to study dissolved inorganic $\mathrm{P}$ dynamics and microbial activity in soils and sediment. Phosphorus has three isotopes $\left({ }^{31} \mathrm{P},{ }^{32} \mathrm{P}\right.$, and $\left.{ }^{33} \mathrm{P}\right)$. The heavier isotopes $\left({ }^{32} \mathrm{P}\right.$ and $\left.{ }^{33} \mathrm{P}\right)$ are radioactive, making direct stable isotope tracing of $\mathrm{P}$ impossible. Fortunately, oxygen is commonly bound to $\mathrm{P}$ as phosphate $\left(\mathrm{PO}_{4}{ }^{3-}\right)$ and is resistant to equilibrium fractionation due to hydrolysis in natural environments; hence, oxygen may be used as a discriminator of $P$ sources and an ambient indicator of $P$ cycling (Young et al., 2009; Elsbury et al., 2009; Davies et al., 2014). The oxygen isotopic composition of phosphate is defined using standard delta notation as:

$$
\begin{aligned}
& \delta^{18} \mathrm{O}_{\mathrm{PO} 4}= \\
& \left(\frac{\left({ }^{18} \mathrm{O} /{ }^{16} \mathrm{O}\right)_{\text {PO4 }}-\left({ }^{18} \mathrm{O} /{ }^{16} \mathrm{O}\right)_{\text {VSMOW }}}{\left({ }^{18} \mathrm{O} /{ }^{16} \mathrm{O}\right)_{\text {VSMOW }}}\right) \times 1000
\end{aligned}
$$

Measurement of $\delta^{18} \mathrm{O}$ values has been performed for DRP in streamwater and for PIP in soils and sediments, which is in-line with most readily measured pools. Regarding DRP, the $\delta^{18} \mathrm{O}_{\mathrm{DRP}}$ signature has been found to be a potentially effective tracer for sources where variable rates of microbial processing are present (Young et al., 2009; Davies et al., 2014). For soils, $\delta^{18} \mathrm{O}_{\mathrm{PO} 4}$ has been used as a source identifier to trace $\mathrm{P}$ movement through the environment, as an indicator of biological activity within soils, and to assess the variability of $\delta^{18} \mathrm{O}_{\mathrm{PO} 4}$ in plant-soil pools (Angert et al., 2012; Tamburini et al., 2012). Tamburini et al. (2014) provided a detailed review of relevant studies. Recently, extraction methods for benthic and transported sediment samples have been developed (Pistocchi et al., 2017). This approach shows promise for tracking in-stream microbial processing of benthic sediment $P$ and for integrating source signatures of upland DRP due to the high affinity of sediments for phosphate adsorption (Pistocchi et al., 2017).

\section{Processes Impacting Stream ISOTOPE COMPOSITIONS}

In this section, we highlight the efficacy of isotope measurements to reflect water quality processes for $\mathrm{C}, \mathrm{N}$, and $\mathrm{P}$ cycles. Figures 2 through 4 highlight the biotic (figs. 2a, 3a, 4a) and abiotic (figs. 2b, 3b, 4b) processes that impact stream C (Ford and Fox, 2015), N (Peterson et al., 2001; Birgand et 
al., 2007; Ford et al., 2017), and P (Withers and Jarvie, 2008). We recognize that processes are often a mixture of biological, chemical, and physical mechanisms (e.g., biochemical reduction of nitrate to dinitrogen gas); therefore, for the purposes of this study, we make the distinction between biotic (biological and biochemical) and abiotic (nonbiological chemical and physical) processes. We highlight the impacts on atmospheric, water, biota, and sediment pools by showing the isotope fractionations and flux contributions to and from each pool.

\section{CARBON}

Biotic uptake of autochthonous biomass and mineralization of organic matter by endogenous and heterotrophic respiration are the primary biotic mechanisms impacting fluvial organic C cycling (fig. 2a; Ford and Fox, 2014, 2017; Hotchkiss and Hall, 2015). Stabilization is a process in which DIC from the streamwater pool is assimilated in autochthonous biomass, and then more complex organic $\mathrm{C}$ compounds are decomposed to fine sediments that have slower rates of decomposition, i.e., compounds that are more recalcitrant to biotic mineralization (Lane et al., 2013). Autochthonous biota, including benthic algae, macrophytes, and phytoplankton, fix dissolved inorganic $\mathrm{C}$ into particulate organic $\mathrm{C}$ during photosynthesis. Regarding uptake, the $\mathrm{C}$ isotopic signature of stabilized autochthonous organic matter is typically low in ${ }^{13} \mathrm{C}$ relative to allochthonous matter due to ${ }^{13} \mathrm{C}$ of DIC that is depleted relative to atmospheric $\mathrm{CO}_{2}$ and has a high isotope fractionation value ( $\varepsilon$ between $15 \%$ and $25 \%$ ) (Sharp, 2007; Tobias and Böhlke, 2011; Ford and Fox, 2015). Sediment decomposition and mineralization of organic $\mathrm{C}$ result in a loss from the sediment or biota pool that is added to the dissolved inorganic pool and may occur in either aerobic or anaerobic conditions. Sediment $\mathrm{C}$ regener-

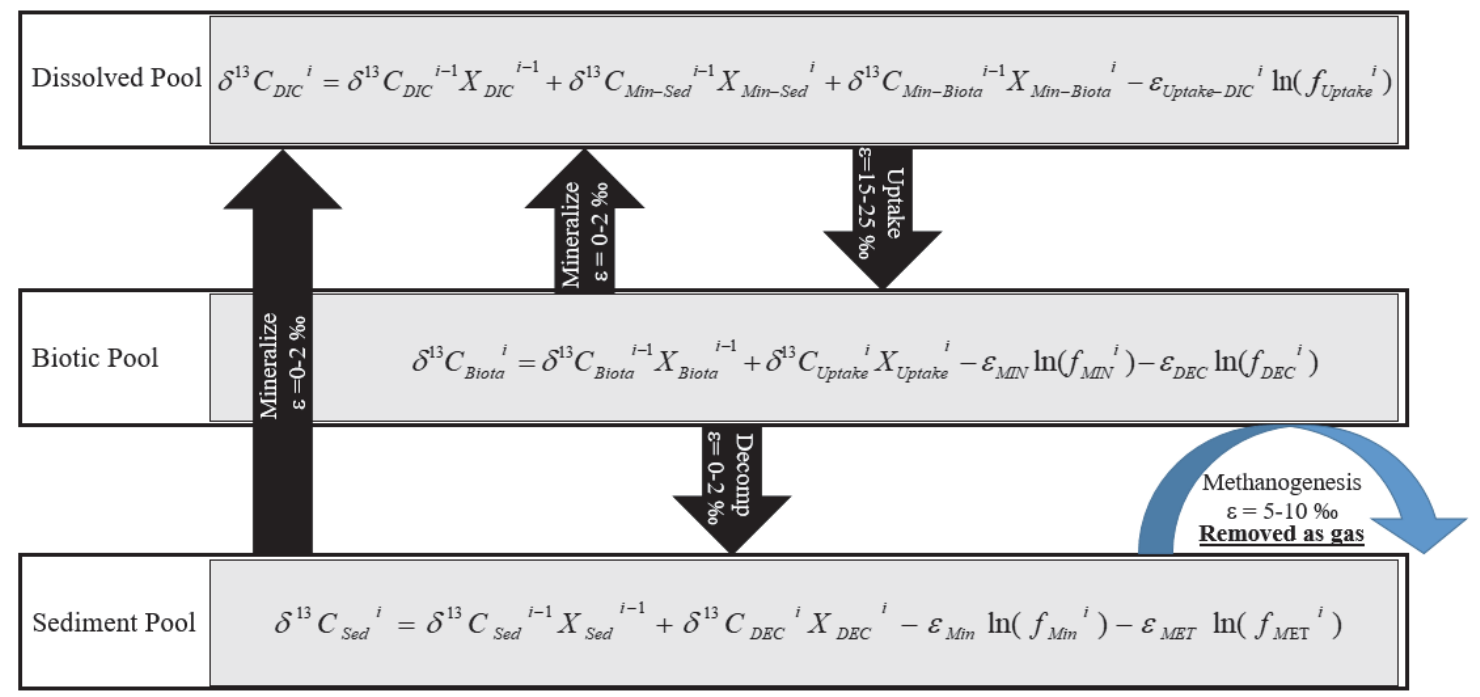

(a)

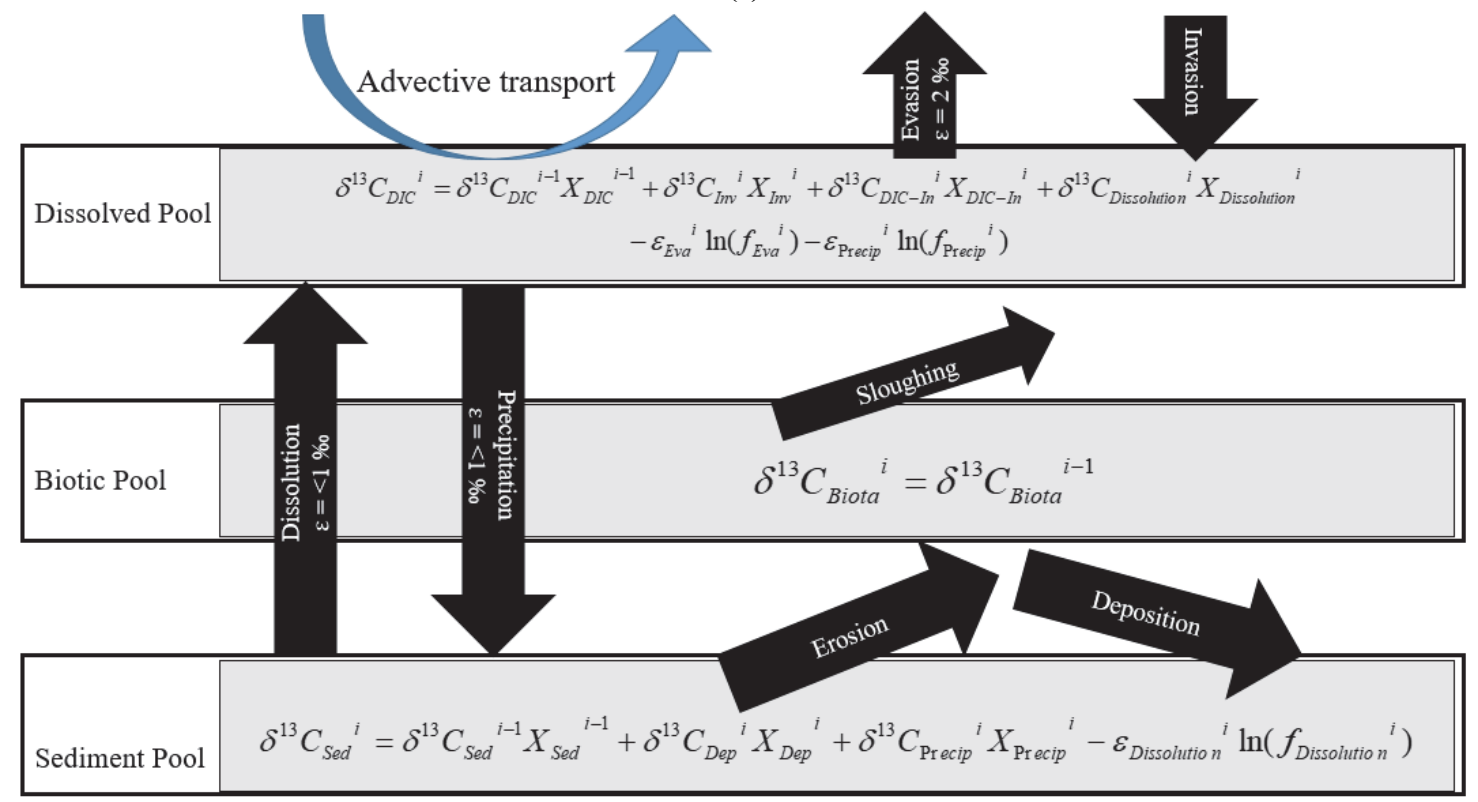

(b)

Figure 2. Depiction of (a) biotic and (b) abiotic processes impacting dissolved, biotic, and sediment $\mathrm{C}$ isotope pools. Where applicable, processes include a range of typical fractionation factors observed in the literature. Mass balance Rayleigh-like equations (extending eq. 9) are shown for the environmentally relevant pools often considered in water quality models. 
ation through oxidation of organic matter to $\mathrm{CO}_{2}$ imparts a small fractionation compared to the autochthonous fractionation on the DIC pool ( $\varepsilon<2 \%$ ) (Jacinthe et al., 2009; Ford and Fox, 2015). Degradation of organic matter to methane under anaerobic conditions may be important in landscapes such as peat bogs, resulting in fractionations of $5 \%$ o to $10 \%$ (Galand et al., 2010).

Prominent abiotic processes impacting the fluvial $\mathrm{C}$ cycle include $\mathrm{CO}_{2}$ flux across the air-water interface, mineral precipitation and dissolution, and hydrodynamic alterations to benthic sediment and biota pools (fig. 2b). $\mathrm{CO}_{2}$ often evades the stream channel and acts as a source to the atmosphere due to the high rates of mineralization in soil water and benthic sediments that lead to excess partial pressures of $\mathrm{CO}_{2}$ in stream water. Both equilibrium $(\varepsilon=1 \%$ ) and kinetic evasion $(\varepsilon=2 \%$ ) fractionations result from DIC exchange with the atmosphere. Precipitation of dissolved inorganic $\mathrm{C}$ is a prominent potential sink for DIC and is balanced by mineral dissolution. Results from Tobias and Böhlke (2011) highlighted carbonate precipitation as an equally important sink to primary production in a low-order stream in an agroecosystem. While algal uptake exerts a strong kinetic isotopic fractionation on the dissolved inorganic pool, precipitationdissolution imparts a small equilibrium fractionation $(\varepsilon<$ 1\%o) (Mook, 2006; Tobias and Böhlke, 2011). The erosiondeposition dynamics of sediment are well documented to impact benthic $\mathrm{C}$ isotopic signatures, which reflect sediment $\mathrm{C}$ quantity and quality (Ford et al., 2015a). Newly deposited sediments are mixed with existing sediments through turbulent advection of the overlying streamwater into the benthos (Russo and Fox, 2012; Ford and Fox, 2014). The level of mixing is scale-dependent, but in low to mid-order streams with high prominence of fine-cohesive sediments, sediment within the surficial fine-grained laminae of the streambed surface is typically well-mixed (Droppo et al., 2000). Fluvial sloughing of algal biomass has the potential to impact sediment isotope compositions, especially in low DIC systems where fractionations due to autochthonous growth in response to biotic population disequilibrium have a larger footprint on the DIC isotope pool (Ford and Fox, 2015). The dynamics for site-specific conditions are discussed further in the "Review of Stable Isotopes in Water Quality Modeling" section.

\section{NitrogeN}

Practically all $\mathrm{N}$ fractionation takes place through biologically mediated pathways, including the aforementioned autochthonous growth, heterotrophic and endogenous respiration (mineralization), nitrification, and denitrification (fig. 3a; Sharp 2007). Regarding autotrophic assimilation of $\mathrm{N}$ species, biotic algal uptake of $\mathrm{N}$ imparts a fractionation on its DIN source of $6 \%$ to $13 \%$ for $\mathrm{NO}_{3}$ (Needoba et al., 2003; Kendall et al., 2007) and 0\%o to 27\%o for $\mathrm{NH}_{4}$ (Fogel and Cifuentes, 1993; Kendall et al., 2007). However, fractionations for ammonium are likely small $(\varepsilon<4 \%$ ) in most aquatic systems with low ammonium concentrations (Fogel and Cifuentes, 1993; Kendall et al., 2007). Regarding N, remineralization of organic $\mathrm{N}$ to ammonium fractionations are typically negligible, with $\varepsilon \pm 1 \%$ (Kendall et al., 2007).
The benefit of $\mathrm{N}$ isotopes to reflect in-stream biotic cycling is recognized from the high fractionations reported for $\mathrm{N}$ and $\mathrm{O}$ isotopes during dissolved inorganic transformation in nitrification and denitrification processes (Kendall et al., 2007). Nitrification is the two-step aerobic oxidation of ammonium $\left(\mathrm{NH}_{4}{ }^{+}\right)$to nitrite $\left(\mathrm{NO}_{2}^{-}\right)$and then to nitrate $\left(\mathrm{NO}_{3}{ }^{-}\right)$. As previously mentioned, $\delta^{15} \mathrm{~N}$ and $\delta^{18} \mathrm{O}$ of nitrate are measured using the dual-isotope approach. With regard to $\delta^{15} \mathrm{~N}$, researchers have found that the first step $\left(\mathrm{NH}_{4}{ }^{+}\right.$to $\left.\mathrm{NO}_{2}{ }^{-}\right)$is often the rate-determining step in ammonium-rich systems and occurs very slowly, resulting in large fractionations on the ammonium $\mathrm{N}$ pool with $\varepsilon$ values ranging from $14 \%$ o to 38\% (Mariotti et al., 1981; Casciotti et al., 2003; Kendall et al., 2007). In ammonium-limited systems, the fractionation of the $\mathrm{N}$ isotope is relatively small. Further, the second step $\left(\mathrm{NO}_{2}\right.$ to $\left.\mathrm{NO}_{3}{ }^{-}\right)$is rapid and typically does not result in a net fractionation. With regard to $\delta^{18} \mathrm{O}$ of nitrate, the oxygen isotope composition will generally reflect a mixture of the oxygen isotope signatures of water and dissolved oxygen; however, the level of fractionation is not well understood (Kendall et al., 2007). For denitrification, or the anaerobic reduction of nitrate to $\mathrm{N}$-based gaseous byproducts, enrichment factors of $\delta^{15} \mathrm{~N}_{\mathrm{NO} 3}$ range from $1 \%$ to $18 \%$ depending on where denitrification occurs (i.e., water column, benthos, riparian zone) (Brandes and Devol, 2002; Sebilo et al., 2003; Lehmann et al., 2004; Sigman et al., 2005; Kendall et al., 2007).

Abiotic processes controlling $\mathrm{N}$ cycling and isotope signatures in-stream not only include the aforementioned hydrodynamic and hydraulic factors (analogous to $\mathrm{C}$ ) but also chemi-physical sorption of DIN to benthic sediments. Abiotic adsorption of ammonium is widely recognized as a transient $\mathrm{N}$ sink, with reported apparent equilibrium fractionations ranging from 1\%o to 11\%o (Delwiche and Steyn, 1970; Karamanos and Rennie, 1978; Bernot and Dodds, 2005; Böhlke et al., 2006). Abiotic adsorption of nitrate in streams is not currently part of the perceptual model (Peterson et al., 2001; Birgand et al., 2007; Ford and Fox, 2017); however, evidence exists for nitrate adsorption to variably charged sesquioxides in benthic sediments, analogous to processes reported in soils (Ford et al., 2015b). Given the limited understanding of the magnitude and significance of this flux, the isotopic fractionation is not well understood; therefore, future work is needed to test the significance of the sorption mechanism and identify potential ranges of isotope fractionation under differing sediment and streamwater chemistry.

\section{PHOSPHORUS}

Regarding biotic processes, the primary mechanism leading to changes in $\delta^{18} \mathrm{O}_{\mathrm{PO} 4}$ is associated with microbial mediated recycling of orthophosphate. Enzymatic breaking of the $\mathrm{P}-\mathrm{O}$ bond during microbial cycling of orthophosphate drives the phosphate signature toward a temperature-dependent equilibrium fractionation value, with $\delta^{18} \mathrm{O}_{\mathrm{H} 2 \mathrm{O}}$ following regeneration to the water column (Young et al., 2009; Davies et al., 2014). Therefore, in areas where microbial P cycling is rapid (e.g., benthic biofilms), the $\delta^{18} \mathrm{O}_{\mathrm{PO} 4}$ of DRP reflects a mixture of its source signature and rates of microbial $P$ regeneration. Regarding sediment and biota $\mathrm{P}$, we did not find 


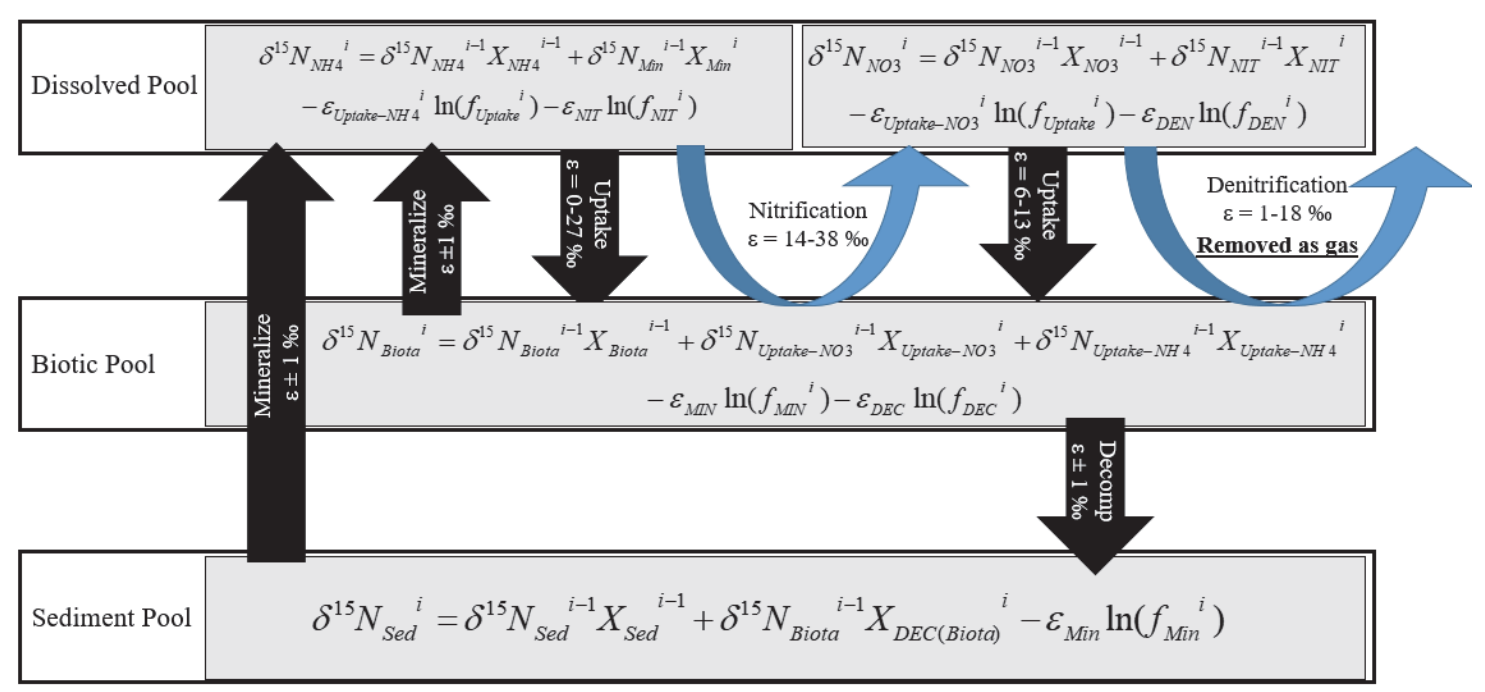

(a)

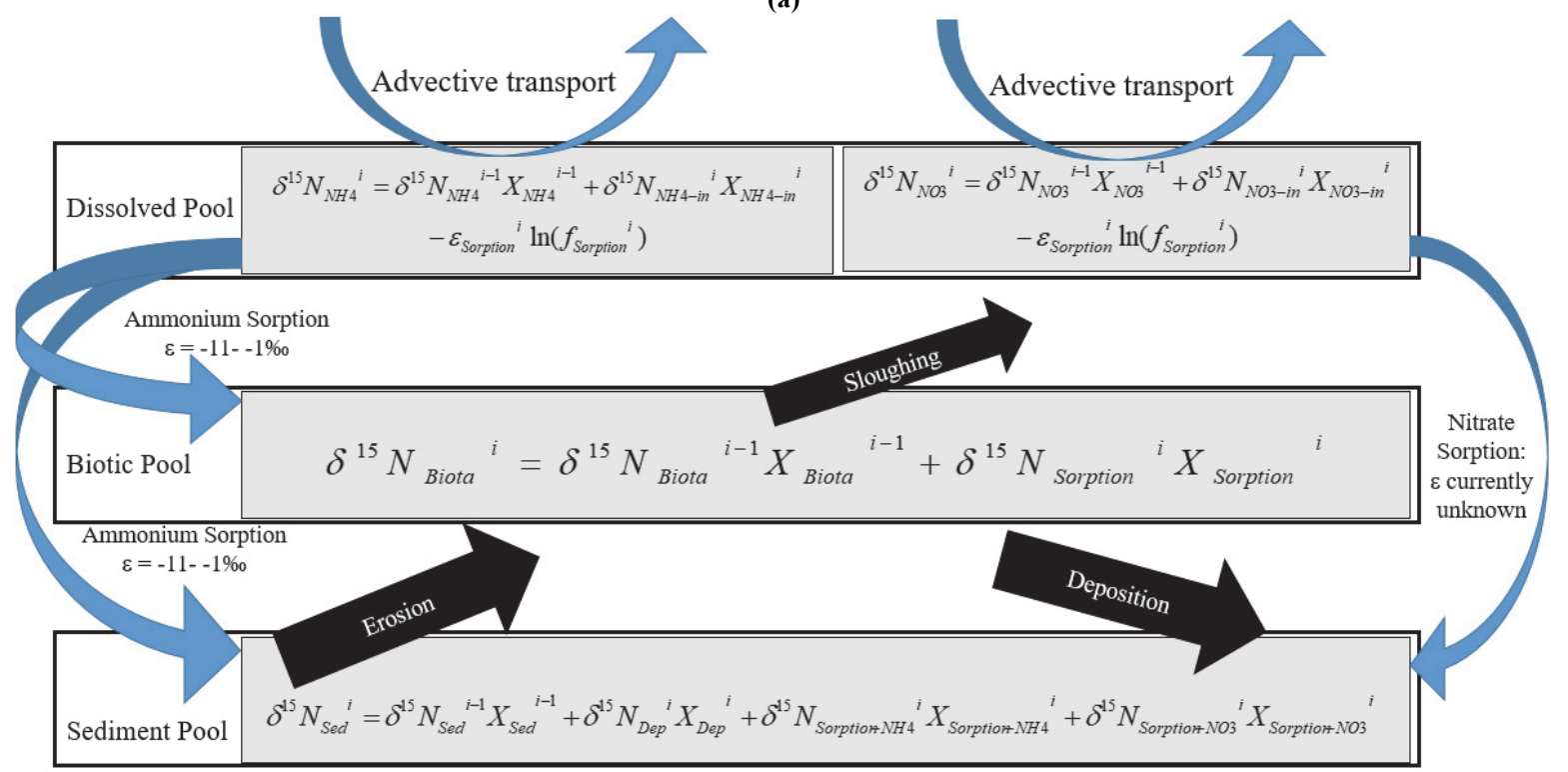

(b)

Figure 3. Depiction of (a) biotic and (b) abiotic processes impacting dissolved, biotic, and sediment $\mathbf{N}$ isotope pools. Where applicable, processes include a range of typical fractionation factors observed in the literature. Mass balance Rayleigh-like equations (extending eq. 9) are shown for the environmentally relevant pools often considered in water quality models.

information on fractionation associated with uptake or mineralization on the sediment or biota pools; however, techniques for measuring sediment $\mathrm{PO}_{4}$ signatures are relatively new and do not explicitly distinguish between organic and inorganic P sources (Pistocchi et al., 2017).

Abiotic processes, including erosion-deposition, precipitation-dissolution, and sorption-desorption, are more significant for fluvial $\mathrm{P}$ cycling than for $\mathrm{C}$ and $\mathrm{N}$, which stems from the high sorption capacity of cohesive soils. Soil $\mathrm{P}$ may be highly stratified in adsorbed inorganic $\mathrm{P}$; hence, erosion deposition dynamics are important in fluvial ecosystems (Jarvie et al., 2014). Authigenic production of orthophosphate occurs through co-precipitation with calcite, precipitation with iron and hydroxide in oxic pore waters, and precipitation as vivianite under anaerobic, eutrophic conditions (Withers and Jarvie, 2008, and references within). The min- eral growth process is rapid, and fractionation effects between mineral and dissolved phosphate are low; hence, the $\delta^{18} \mathrm{O}$ signature of authigenic $\mathrm{P}$ commonly reflects its phosphate source, and vice versa for dissolution (Joshi et al., 2015). P uptake through sorption is widely acknowledged within streams and may be a significantly higher sink of $\mathrm{P}$ as compared with algal assimilation (Withers and Jarvie, 2008). Further, P desorption may become a prominent source of legacy $\mathrm{P}$ under specific redox conditions in agroecosystems, which tend to retain rich stores of $\mathrm{P}$ in benthic sediments (Jarvie et al., 2014; Joshi et al., 2015; Baker et al., 2017). Oxygen isotope signatures of phosphate are not subjected to equilibrium fractionations under abiotic processes; hence, phosphate adsorped to sediment surfaces should reflect its inorganic $\mathrm{P}$ source and its regenerated product (Davies et al., 2014). 


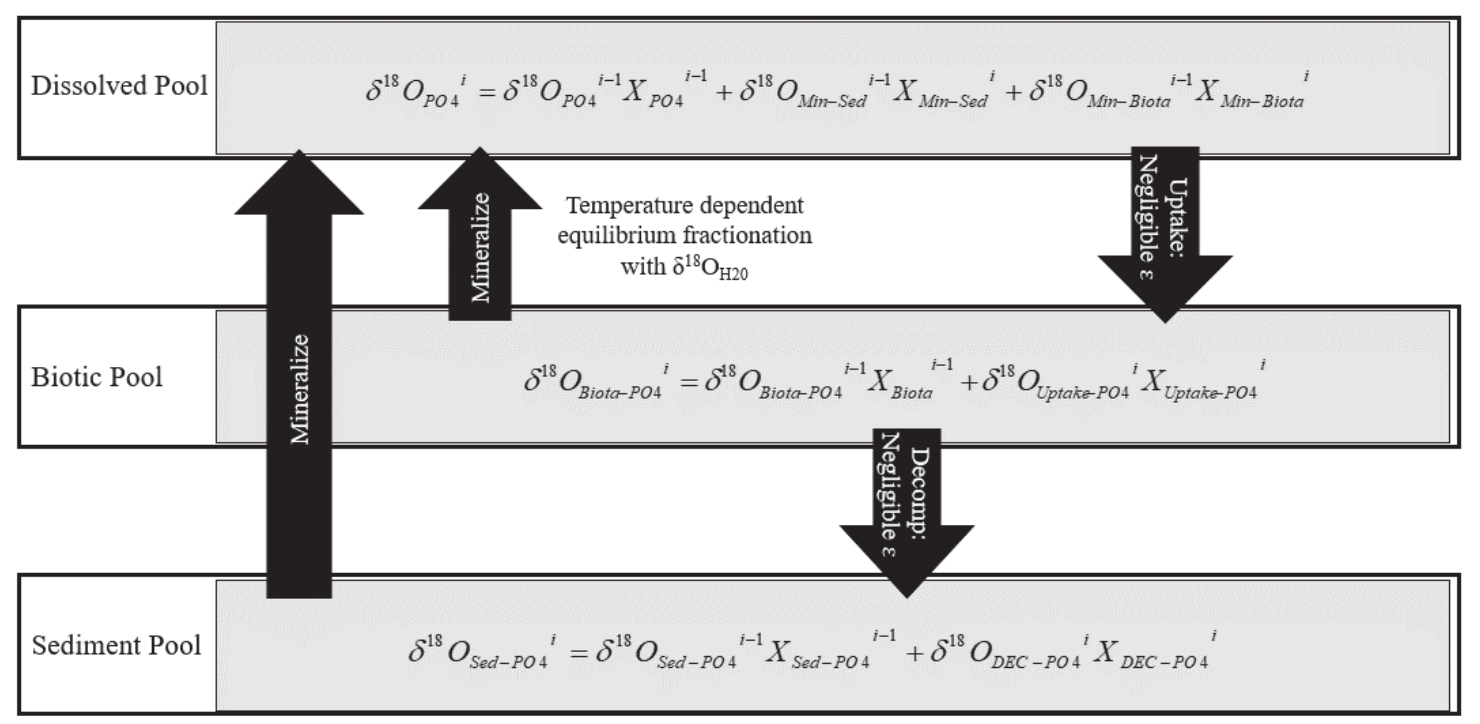

(a)

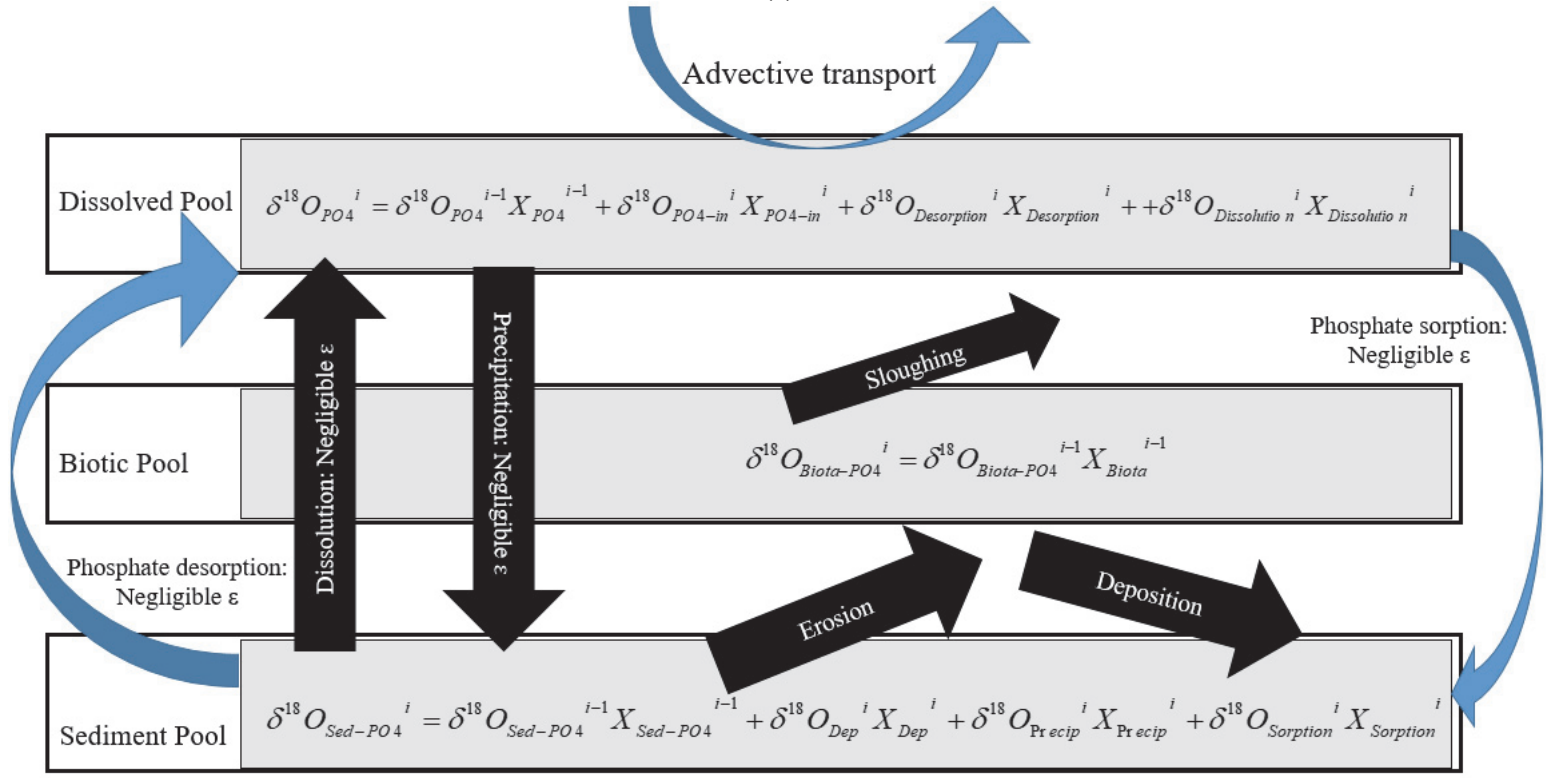

(b)

Figure 4. Depiction of (a) biotic and (b) abiotic processes impacting dissolved, biotic, and sediment $P$ isotope pools. Where applicable, processes include a range of typical fractionation factors observed in the literature. Mass balance Rayleigh-like equations (extending eq. 9) are shown for the environmentally relevant pools often considered in water quality models.

\section{REVIEW OF STABLE ISOTOPES IN WATER Quality Modeling}

Coupling of stable isotopes within water quality models is in its infancy within the water resources community, and there are likely many permutations of coupling that may be performed in future research and model development. Nevertheless, based on our review of previous research as well as research advancements in recent years, we highlight three common themes defined earlier in this article, i.e., that stable isotopes are coupled with water quality models to (1) improve data inputs associated with boundary conditions of the models, (2) constrain model parameterization associated with equifinality, and (3) elucidate improvements needed within the model structure. Table 2 highlights the relevant watershed water quality modeling studies reported in the literature. Specifically, we provide summaries of how each study addresses one or more of the themes. As will be shown, at least one of the uncertainty-associated components was overcome when the researchers coupled stable isotopes within their watershed water quality modeling. To our knowledge, these studies represent an exhaustive list of water quality modeling applications that incorporate stable isotopes of $\mathrm{C}$ and $\mathrm{N}$. In this manner, current use of stable isotopes in water quality modeling has highlighted their utility for improving reliability and reducing equifinality in hydrologic and water quality model simulations. We have separated this section into $\mathrm{C}$ and $\mathrm{N}$ isotope applications because no applications for $\mathrm{P}$ have been performed to date.

\section{CARBON}

\section{Dissolved Carbon}

Tobias and Böhlke (2011) quantified the relative amounts of biological and geochemical controls on DIC cycling and 
Table 2. Review of watershed water quality modeling studies using stable isotopes of nutrients and sediment to improve boundary condition estimates, improve perceptual understanding of $C, N$, and $P$ pathways and model structure, and constrain uncertainty.

\begin{tabular}{|c|c|c|c|c|c|}
\hline \multirow[b]{2}{*}{ Reference } & \multirow[b]{2}{*}{$\begin{array}{c}\text { Isotope } \\
\text { Parameters } \\
\text { Used }\end{array}$} & \multirow[b]{2}{*}{$\begin{array}{l}\text { Watershed Water Quality } \\
\text { Modeling Application }\end{array}$} & \multicolumn{3}{|c|}{ Benefits of Using the Isotopes } \\
\hline & & & $\begin{array}{c}\text { Establishing } \\
\text { Boundary Conditions }^{[\mathrm{a}]} \\
\end{array}$ & $\begin{array}{l}\text { Constraining Uncertainty } \\
\text { of Biogeochemical Cycling }\end{array}$ & $\begin{array}{c}\text { Improving Perceptual } \\
\text { Understanding of C, N, or P } \\
\text { Pathways and Model Structure }\end{array}$ \\
\hline $\begin{array}{c}\text { Fox et al., } \\
2010\end{array}$ & $\delta^{15} \mathrm{~N}_{\text {sediment }}$ & $\begin{array}{l}\text { To model sediment transport (in- } \\
\text { cluding temporarily stored } \\
\text { streambed sediments) and separate } \\
\text { sediment source contributions at } \\
\text { the outlet of a lowland watershed. }\end{array}$ & $\begin{array}{l}\text { Streambank and surface } \\
\text { soils separated through the } \\
\text { use of } \delta^{15} \mathrm{~N} \text { and } \mathrm{C}: \mathrm{N} \text { signa- } \\
\text { tures from collected pas- } \\
\text { ture and surface soils. }\end{array}$ & - & $\begin{array}{l}\text { Showed the fate of the total } \mathrm{N} \text { and } \\
\delta^{15} \mathrm{~N} \text { signature of the temporarily } \\
\text { stored streambed sediments. }\end{array}$ \\
\hline $\begin{array}{l}\text { Tobias and } \\
\text { Böhlke, } \\
2011\end{array}$ & $\begin{array}{c}\delta^{13} \mathrm{C}_{\mathrm{DIC}} \\
\delta^{18} \mathrm{O}_{\mathrm{O} 2}\end{array}$ & $\begin{array}{l}\text { To quantify rates of photosynthesis, } \\
\text { respiration, groundwater discharge, } \\
\text { air-water exchange of } \mathrm{CO}_{2} \text {, and } \\
\text { carbonate precipitation and dissolu- } \\
\text { tion. }\end{array}$ & - & $\begin{array}{l}\text { Use of } \delta^{18} \mathrm{O}_{\mathrm{O} 2} \text { helps to constrain } \\
\text { the interpretations of } \delta^{13} \mathrm{C}_{\mathrm{DIC}} \text { meas- } \\
\text { urements and DIC data; C isotopes } \\
\text { are useful for confirming appropri- } \\
\text { ate photosynthesis and respiration } \\
\text { rates on which the DIC budget is } \\
\text { framed. }\end{array}$ & $\begin{array}{l}\text { Chemical and isotope modeling } \\
\text { used with diel observations aids } \\
\text { in mechanistic understanding of } \\
\text { reactions and environmental fac- } \\
\text { tors that contribute to patterns of } \\
\text { DIC fate and transport. }\end{array}$ \\
\hline $\begin{array}{c}\text { Van Engeland } \\
\text { et al., } 2012\end{array}$ & $\delta^{13} \mathrm{C}_{\text {DIC }}$ & $\begin{array}{l}\text { To predict carbon cycling under } \\
\text { differing } \mathrm{CO}_{2} \text { systems within a } \\
\text { controlled environment to study } \\
\text { ocean acidification effects. }\end{array}$ & - & $\begin{array}{l}\text { Labeled } \delta^{13} \mathrm{C}_{\mathrm{DIC}} \text { injections into } \\
\text { mesocosm experiments helped ex- } \\
\text { pand the data set used for calibra- } \\
\text { tion, which resulted in independent } \\
\text { parameter values leading to a more } \\
\text { constrained model output. }\end{array}$ & - \\
\hline $\begin{array}{l}\text { Hong et al., } \\
2014\end{array}$ & $\delta^{15} \mathrm{~N}_{\text {biota }}$ & $\begin{array}{l}\text { To model the fate, transport, and } \\
\text { bioaccumulation of } \mathrm{CH}_{3} \mathrm{Hg}^{+} \text {and } \\
\text { look at mercury distributions to as- } \\
\text { sess health risks to humans and bi- } \\
\text { ota surrounding and within the wa- } \\
\text { terbody. }\end{array}$ & $\begin{array}{l}\text { Modeling showed where } \\
\text { mercury loading was oc- } \\
\text { curring and how it was be- } \\
\text { ing discharged into the wa- } \\
\text { terbody. }\end{array}$ & $\begin{array}{l}\text { Uncertainty of biogeochemical pro- } \\
\text { cesses in calculating mercury levels } \\
\text { in fish tissues reduced from rela- } \\
\text { tionship between mercury and } \delta^{15} \mathrm{~N} \\
\text { concentrations. }\end{array}$ & $\begin{array}{l}\text { By modeling a linear relationship } \\
\text { between logarithmic mercury } \\
\text { concentrations and } \delta^{15} \mathrm{~N} \text {, the fate, } \\
\text { transport, and bioaccumulation of } \\
\mathrm{CH}_{3} \mathrm{Hg}^{+} \text {was shown. }\end{array}$ \\
\hline $\begin{array}{l}\text { Sebestyen } \\
\text { et al., } 2014\end{array}$ & $\begin{array}{l}\delta^{15} \mathrm{~N}_{\mathrm{NO} 3-} \\
\delta^{18} \mathrm{O}_{\mathrm{NO} 3-}\end{array}$ & $\begin{array}{l}\text { To study timing, length, and mag- } \\
\text { nitude of stream nitrate changes, } \\
\text { DON, and } \mathrm{NH}_{3} \text {; to study changes in } \\
\text { nitrate sources and cycling; and to } \\
\text { study source areas that heavily in- } \\
\text { fluence } \mathrm{N} \text { dynamics. }\end{array}$ & $\begin{array}{l}\text { Isotopes assist in estimat- } \\
\text { ing source contributions of } \\
\text { nitrate to the stream chan- } \\
\text { nel. }\end{array}$ & - & $\begin{array}{l}\text { Higher inputs of unprocessed at- } \\
\text { mospheric nitrate were found rel- } \\
\text { ative to what is commonly } \\
\text { acknowledged for non-snowmelt } \\
\text { periods in forested landscapes. }\end{array}$ \\
\hline $\begin{array}{c}\text { Xue et al., } \\
2014\end{array}$ & $\begin{array}{c}\delta^{15} \mathrm{~N}_{\mathrm{NO} 3-} \\
\delta^{18} \mathrm{O}_{\mathrm{NO} 3-} \\
\delta^{11} \mathrm{~B}\end{array}$ & $\begin{array}{l}\text { Apportionment of nitrate sources in } \\
\text { surface water from five potential } \\
\text { sources. }\end{array}$ & $\begin{array}{l}\text { Major sources of nitrates } \\
\text { were identified, and their } \\
\text { proportional input was } \\
\text { quantified. }\end{array}$ & - & - \\
\hline $\begin{array}{l}\text { Fox and } \\
\text { Martin, } \\
2014\end{array}$ & $\begin{array}{l}\delta^{13} \mathrm{C}_{\text {sediment }}, \\
\delta^{15} \mathrm{~N}_{\text {sediment }}\end{array}$ & $\begin{array}{l}\text { Estimating yield of sediment } \\
\text { source end member contribution } \\
\text { from different land uses in a water- } \\
\text { shed. }\end{array}$ & $\begin{array}{l}\text { Isotopes separated forest, } \\
\text { reclaimed mine, and } \\
\text { streambank sources in wa- } \\
\text { tersheds. }\end{array}$ & $\begin{array}{l}\text { Further calibration of the transport } \\
\text { capacity coefficient, sediment de- } \\
\text { livery ratio, and streambank ero- } \\
\text { sion parameters was found through } \\
\text { the use of sediment fingerprinting. }\end{array}$ & - \\
\hline $\begin{array}{l}\text { Ford and Fox, } \\
2015\end{array}$ & $\begin{array}{c}\delta^{13} \mathrm{C}_{\text {DIC }}, \\
\delta^{13} \mathrm{C}_{\text {sediment }}\end{array}$ & $\begin{array}{l}\text { Estimation of the fluvial organic } \\
\text { carbon budget of streams with ben- } \\
\text { thic autochthonous carbon. }\end{array}$ & $\begin{array}{l}\text { Input parameterization of } \\
\text { allochthonous sediment } \\
\text { sources and DIC pool. }\end{array}$ & $\begin{array}{l}80 \% \text { reduction in uncertainty of al- } \\
\text { gal C fluxes due to the sensitivity } \\
\text { of the isotope response variable to } \\
\text { algal sloughing. }\end{array}$ & - \\
\hline $\begin{array}{l}\text { Adiyanti } \\
\text { et al., } 2016\end{array}$ & $\begin{array}{l}\delta^{13} \mathrm{C}_{\mathrm{DIC}} \\
\delta^{13} \mathrm{C}_{\mathrm{DOC}}\end{array}$ & $\begin{array}{l}\text { To quantify carbon cycling in an } \\
\text { estuary. }\end{array}$ & - & $\begin{array}{l}\text { Reduce equifinality of the model } \\
\text { through addition of direct con- } \\
\text { straints on matter and energy trans- } \\
\text { fer between pools. }\end{array}$ & - \\
\hline $\begin{array}{l}\text { Ford et al., } \\
2017\end{array}$ & $\begin{array}{c}\delta^{15} \mathrm{~N}_{\mathrm{NO} 3} \\
\delta^{15} \mathrm{~N}_{\text {sediment }}\end{array}$ & $\begin{array}{l}\text { To quantify the significance of } \\
\text { transient and permanent removal } \\
\text { pathways. }\end{array}$ & - & $\begin{array}{l}\text { Reduce model uncertainty from er- } \\
\text { roneous parameterization of a flu- } \\
\text { vial N cycle by applying sediment } \\
\mathrm{N} \text { fingerprints. }\end{array}$ & $\begin{array}{l}\text { Discrepancy in isotope measure- } \\
\text { ments and model simulations at } \\
\text { event-based scales highlight lim- } \\
\text { ited understanding of mobiliza- } \\
\text { tion and demobilization through } \\
\text { biotic and abiotic pathways. }\end{array}$ \\
\hline $\begin{array}{l}\text { Husic et al., } \\
2017 b\end{array}$ & $\delta^{13} \mathrm{C}_{\text {sediment }}$ & $\begin{array}{l}\text { To model time-distributed pro- } \\
\text { cesses that control the fate of sedi- } \\
\text { ment carbon in phreatic karst. }\end{array}$ & $\begin{array}{l}\text { Fingerprinting was used to } \\
\text { unmix soil, algal, and litter } \\
\text { contributions from urban } \\
\text { and agricultural tributaries } \\
\text { to a karst conduit. }\end{array}$ & - & - \\
\hline
\end{tabular}

[a] Studies involving isotope mass balance unmixing are not included; nevertheless, they support the concept of establishing boundary conditions.

flux within a $1 \mathrm{~km}$ first-order agricultural stream reach using daily $\delta^{13} \mathrm{C}$ of DIC and $\delta^{18} \mathrm{O}$ of $\mathrm{O}_{2}$ applied to a finite-differencing mass balance model. Their use of $\delta^{18} \mathrm{O}_{\mathrm{O} 2}$ was to aid in constraining interpretations of the $\delta^{13} \mathrm{C}_{\mathrm{DIC}}$ and DIC measurements. Their logic was that when chemical and isotope modeling is applied in combination with daily observations, there would be an improvement in the overall mechanistic understanding of the diel fluctuations and environmental factors that influence DIC fate and transport. The model output contrasted with the collected data in that the model $\delta^{13} \mathrm{C}_{\mathrm{DIC}}$ estimates were too high and did not reproduce cation cycles. The values of input parameters needed to reproduce accurate output values were unrealistically high, and the insensitivity of the $\delta^{13} \mathrm{C}_{\text {DIC }}$ variation to carbonate reaction suggested that the indicator acted as a poor indicator of diel processes except for photosynthesis rates in highly productive systems.

Stable isotope signatures of DIC ( $\left.\delta^{13} \mathrm{C}_{\text {DIC }}\right)$ have recently been implemented in marine and estuarine environments to reduce equifinality. Van Engeland et al. (2012) investigated model uncertainty reduction through inclusion of $\delta^{13} \mathrm{C}_{\mathrm{DIC}}$ results for injected mesocosm experiments into a marine nitro- 
gen-phytoplankton-zooplankton-detritus (NPZD) model. Equifinality was reduced by explicitly resolving stable isotope dynamics within the parametric modeling framework. The additions of the $\delta^{13} \mathrm{C}_{\text {DIC }}$ tracers constrained uncertainty of biogeochemical transformations of the model-predicted rates and fluxes associated with $\mathrm{C}$ mass balance. Evaluation of the NPZD model with and without isotope calibration data was performed. The authors found that calibrations using solely concentration data exhibited higher standard deviations of uncertain parameters, strong correlations between fitted parameters (suggesting parameter value dependence), and inaccurate estimates of zooplankton grazing and detritus sinking rates as compared with multi-objective calibration with concentration and stable isotope response variables. Quantitatively, the authors provide evidence of this through a higher multicollinearity index for the reduced (no isotope) dataset relative to the full model evaluation dataset (values of 3.43 and 1.64 , respectively).

Adiyanti et al. (2016) collected high spatial resolution data in a subtropical estuary over five sampling campaigns and analyzed samples for dissolved inorganic, dissolved organic, and POC isotope signatures. The authors used a mixed 1-D, 3-D modeling approach that coupled hydrodynamics with $\mathrm{C}$ biogeochemistry for the estuary and used DIC and DOC isotope and concentration measures as model response variables. The authors highlight that the addition of the isotope response variables allowed better constraint for biogeochemical process parameters as compared to using Markov chain Monte Carlo optimization without the isotopes. Parameter space constraint was observed because of sensitive fractionation effects on the isotope response variables that led to rejection of implausible model outputs. The authors highlight the utility of the approach for advancing $\mathrm{C}$ budgeting by using the model to describe spatial variability of the trophic state within the estuary.

\section{Particulate Carbon}

Sediment particulate $\mathrm{C}$ isotope signatures $\left(\delta^{13} \mathrm{C}_{\mathrm{FPOC}}\right)$ have been used to improve model calibration and parameterization for conservative and non-conservative tracer behavior. Fox and Martin (2014) used stable sediment $\mathrm{C}$ and $\mathrm{N}$ isotopes of sediment to separate forest, reclaimed mine, and streambank sources and to highlight the efficacy of coupling stable isotope fingerprinting with deterministic sediment yield modeling in mixed-use landscapes. Carbon isotopes were used in conjunction with $\mathrm{N}$ isotopes as a dual-tracer approach to estimate time-varying sediment source contributions within the watersheds, subsequently acting as an additional response variable in sediment yield model evaluation. The authors used the added isotope-based response variable to calibrate the sediment transport capacity coefficient, sediment delivery ratio for reclaimed mining soils, and streambank erosion parameters. The source uniqueness and timevarying nature of the forest source allowed the authors to elucidate the impact of reclamation practices on sediment yield with their model. The authors' study was found to be applicable for steep-gradient watersheds with relatively conservative tracers (in-stream) due to low residence time.

For non-conservative systems (e.g., low-gradient agroecosystems with pronounced sediment storage), Ford et al. (2015a) used stable $\mathrm{C}$ isotopes of transported sediments $\left(\delta^{13} \mathrm{C}_{\mathrm{FPOC}}\right)$ to constrain a reach-scale $\mathrm{C}$ fate and transport model that considered benthic autochthonous and terrestrial $\mathrm{C}$ sources. A deterministic $\mathrm{C}$ mass balance model for benthic sediment, algae, and DIC pools (ISOFLOC) was coupled to a sediment storage and transport model to assess the impact of algae on the fluvial $\mathrm{C}$ budget. Stable isotope mass balances were simulated for each $\mathrm{C}$ pool, and eight years of ambient concentrations of fine POC and $\mathrm{C}$ isotope data were used to evaluate the model. The isotope response variable was found to be highly sensitive to the critical shear stress of algae and the algal POC source (DIC) and its time-varying isotope signature. As a result, calibration using the isotope submodel reduced uncertainty of sloughed algal fluxes by $80 \%$. These highly dependent relationships between biogeochemical processes, physical processes, and the ability of stable isotopes to reflect these processes highlight the importance of ambient isotope response variables to account for non-conservative contaminant behavior in complex fluvial systems.

Sediment stable isotopes of $\mathrm{C}$ have also been effectively used to establish boundary conditions of sediment $\mathrm{C}$ sources. Husic et al. (2017a, 2017b) applied sediment C fingerprinting at the upstream monitoring station of a phreatic karst conduit in central Kentucky. The authors separated sediment $\mathrm{C}$ fractions from surface stream autochthonous detritus, labile terrestrial soil $\mathrm{C}$, and relatively recalcitrant soil $\mathrm{C}$ sources. Given the variability of biological turnover rates of these $\mathrm{C}$ pools and the subsequent implications for water quality in perennial springs that serve as drinking water supplies, the authors highlight the potential utility of the approach. Further, the authors discuss the enhanced adoption of sediment fingerprinting within the hydrologic and water quality community, highlighting the natural linkage to the water quality modeling community.

\section{NiTROGEN}

\section{Dissolved Nitrogen}

Xue et al. (2014) used unmixed isotope inputs for a model that was unlike the other studies reviewed here because the model was not a physically based mechanistic model; however, it included isotopes as inputs for a decision tree model. The study used two years of monthly $\delta^{15} \mathrm{~N}_{\mathrm{NO} 3}$ and $\delta^{18} \mathrm{O}_{\mathrm{NO} 3}$ data from a multitude of sampling locations as inputs for a mixing model (SIAR) to determine nitrate source apportionment. The study also assessed the effectiveness of isotopic data as input in a decision tree model that used physicochemical data. In decision tree models, a critical component of their construction is the split selection, which involves choosing the best option to proceed with in the model. The decision tree model was simulated with and without isotope data, and the isotope data did not improve the performance of the decision tree model. The authors speculated that this could have been due to the complex land use of the study site that resulted in scattered nitrate isotope values. However, the authors posited that an opportunity exists to use $\delta^{15} \mathrm{~N}_{\mathrm{NO} 3}$ and $\delta^{18} \mathrm{O}_{\mathrm{NO} 3}$ data to cultivate a dependable nitrate polluting activity classification.

Sebestyen et al. (2014) used a dual-isotope method of ni- 
trate $\left(\delta^{15} \mathrm{~N}_{\mathrm{NO} 3}\right.$ and $\left.\delta^{18} \mathrm{O}_{\mathrm{NO} 3}\right)$ to study $\mathrm{N}$ cycling and source contributions during autumn in a forested stream ecosystem. Their study combined the interactions among biogeochemical processes, $\mathrm{N}$ source allocation, and flow paths to investigate how these components affect $\mathrm{N}$ variation. Modeling consisted of streamwater and solute mass balances and stable isotope mass balances with Rayleigh fractionations. Inclusion of the stable isotopes improved the constraint of stream biochemical reactions and source contributions. Model estimates suggested that in-stream transformations retained $72 \%$ of the nitrate entering the stream channel. Further, through the isotope mass balance approach, the study found higher inputs of unprocessed atmospheric nitrate than what is commonly acknowledged for non-snowmelt periods in forested landscapes.

\section{Particulate Nitrogen}

Fox et al. (2010) focused on modeling sediment transport and sediment source apportionment using $\mathrm{N}$ stable isotopes $\left(\delta^{15} \mathrm{~N}_{\text {FPN }}\right)$. Their study used $\mathrm{N}$ stable isotopes in sediment to aid in differentiating sediment sources and modeling sediment transport because of the effectiveness of $\delta^{15} \mathrm{~N}$ in separating sediment sources in watersheds that contain vegetation with similar photosynthetic pathways. Nevertheless, the authors found that $\delta^{15} \mathrm{~N}_{\mathrm{FPN}}$ (and sediment $\mathrm{N}$ ) varied substantially due to physical and biogeochemical processes impacting the transient storage zones in sediments. While their study did not examine robust uncertainty analysis for biogeochemical parameters, it highlighted the efficacy of the stable isotopes to help establish inputs from upland and bank sediment sources and highlighted the importance of the fate of $\mathrm{N}$ isotope tracers in productive agroecosystems.

Building on Fox et al. (2010) and Ford and Fox (2015), Ford et al. (2017) developed a reach-scale N model to simulate in-stream $\mathrm{N}$ fate and transport in low-gradient agroecosystems. The $\mathrm{N}$ model that includes stable $\mathrm{N}$ isotope subroutines is known as TRANSFER (Technology for Removable Annual Nitrogen in Streams For Ecosystem Restoration). The authors coupled $\mathrm{N}$ mass balances for dissolved and particulate phases to the previously developed ISOFLOC model (see the preceding "Particulate Carbon" section) and included an $\mathrm{N}$ stable isotope mass balance equation for each of the elemental mass balances. During model evaluation of a case study, the authors found that fine $\mathrm{PN}$ isotope signatures $\left(\delta^{15} \mathrm{~N}_{\mathrm{FPN}}\right)$ were sensitive to sediment sources and non-conservative in-stream sediment $\mathrm{N}$ generation from autochthonous material and organic $\mathrm{N}$ degradation (and hence isotopic signatures of DIN). As a result, the authors reduced equifinality of the estimates of transient DIN removal via algal sloughing and permanent removal via denitrification. Their results showed that reduction of uncertainty by combining sediment elemental and isotope calibration parameters to DIN concentrations resulted in a $67 \%$ reduction from the original parameter solution space for downstream DIN flux estimates. This is compared to a $44 \%$ reduction from the original parameter solution space when calibrating with DIN concentrations alone. The reduced equifinality elucidated the significance of the transient DIN store and the potential for overestimation of denitrification during sensitive timeframes (e.g., late summer/early fall), when sloughed al- gal biomass may potentially fuel harmful and nuisance algal blooms (HNABs) downstream. In addition, the case study revealed disagreement between measured and modeled results for the isotope response variable during winter/spring, potentially highlighting limitations in existing perceptual models for in-stream $\mathrm{N}$ fate and transport, such as the lack of inclusion of abiotic mobilization/demobilization.

Hong et al. (2014) used $\delta^{15} \mathrm{~N}$ signatures in dolphins to determine methyl mercury $\left(\mathrm{CH}_{3} \mathrm{Hg}\right)$ dietary exposure in Sarasota Bay. The $\mathrm{N}$ stable isotope aided in identifying where mercury loading was present and how it was being discharged into the bay system. When one bioconcentration factor in lower trophic level organisms and one biomagnification rate were coupled with a predetermined $\delta^{15} \mathrm{~N}$, the mercury distributions in the ecosystem were successfully reproduced. This relationship enabled modeling of the fate, transport, and bioaccumulation of monomethyl mercury within the waterbody.

\section{RECOMMENDATIONS FOR ISOTOPES IN WATER QUALITY MODELS}

Synthesis of the studies in table 2 points to the ability of stable isotopes to constrain uncertainty of hydrologic and water quality models, improve perceptual understanding of in-stream contaminant fate, and establish boundary conditions for in-stream models. Consistent with the themes recognized in the literature review, we provide some recommendations and precautions for water quality modelers to integrate stable isotopes into new and existing models.

\section{RECOMMENDATION 1: \\ Use Isotopes of Sediments Because They Integrate Processes, Reflect Source Contributions, and Are Inexpensive to Measure}

We perceive high utility in the integration of sediment stable isotopes into in-stream routines in water quality modeling frameworks, given the following factors: the integrative capacity of benthic sediments, the abundance of sediment stable isotope data from watershed sediment source apportionment, the utility of stable isotopes to improve water quality modeling structure and uncertainty reduction, and the now inexpensive costs associated with stable isotope analyses of solids. Sediment fingerprinting has been a popular method for sediment source apportionment over the past 20 years (Collins et al., 1998; Fox and Papanicolaou, 2007; Davis and Fox, 2009). Sediment source apportionment using stable $\mathrm{C}$ and $\mathrm{N}$ isotopes is limited by the fate of the organic matter in the system (Davis and Fox, 2009; Koiter et al., 2013). In part, this non-conservative behavior reflects processes such as the stabilization of algal biomass through algal decomposition to fine sediment and integration into the benthos, and the sorption-desorption of $\mathrm{N}$ phases onto fine sediment aggregates (see the "Processes Impacting Stream Isotope Compositions" section). Therefore, sediment fingerprints reflect not only the upland organic matter and sediment sources but also the rates of processes and the dissolved inorganic nutrient species. For this reason, we foresee high utility in integrating the widespread measurements of $\mathrm{C}$ and 
$\mathrm{N}$ isotopes that have been collected across a broad range of landscapes to test and improve water quality models. Further, we recommend integration of sediment stable isotope measurements into routine water quality monitoring efforts because the sampling equipment is easy to build using standard household items, the data reflect temporal and spatially integrated measures of in-stream transported sediment $\mathrm{C}$ and $\mathrm{N}$ signatures over the course of an event (Phillips et al., 2000), and the data are relatively inexpensive to process and analyze in the laboratory. We caution that sediment stable isotope signatures should be used as a supplement, not as a replacement, for concentration response variables in water quality modeling. Nevertheless, we foresee that the low cost and relatively low processing time for analysis makes this added response variable a plausible supplementary data collection effort in watershed-based monitoring and modeling programs.

\section{RECOMMENDATION 2: \\ Modelers Should Use Multi-Objective \\ Calibration when Using Isotopes}

We highlight the importance of using isotope response variables in multi-objective calibration frameworks to reduce issues with model equifinality. Multi-objective calibration refers to the process of using a set number of weighted numerical metrics that target specific aspects of goodnessof-fit between model results and measured data (Van Griensven and Bauwens, 2003; Rode et al., 2007; Ford and Fox, 2015; Haas et al., 2016). A thrifty approach that has greatly extended the utility of existing concentration data is to use time-varying, multi-objective calibration, whereby calibration statistics are calculated for specific periods to target calibrating parameters when they have heightened sensitivity, i.e., baseflow versus event flow, seasonal performance, and rising versus falling limb of the chemograph (e.g., Haas et al., 2016). Such sensitivities may be identified using time-varying global sensitivity analysis approaches (Reusser et al., 2011; Muleta, 2012; Wang et al., 2013; Herman et al., 2013; Ford and Fox, 2015). Nevertheless, issues persist with using concentration-based measures because they may be insensitive to nutrient residence times, i.e., transient storage and discriminating rates of in-stream processes (e.g., Jarvie et al., 2014; Ford and Fox, 2017). In this light, integration of isotope response variables within a multi-objective framework may be highly valuable, especially given the widely recognized utility to reduce equifinality, as discussed in the "Review of Stable Isotopes in Water Quality Modeling" section.

\section{RECOMMENDATION 3: \\ Water Quality Modelers Should Work Collaboratively with Isotope Geochemists}

With continued advancements in isotope measurement techniques and technology, watershed modelers need to work closely with isotope geochemists to integrate stable isotope measurements into water quality modeling frameworks. From a management perspective, engineers need high-resolution data, especially during storm fluxes, to accurately characterize loadings and source contributions of nutrient fluxes at the watershed scale. Current measurement techniques for grab sample analysis for isotopic measurements of dissolved nutrients are rather expensive, labor intensive, and limit the economic feasibility of high-resolution measurements. Nevertheless, we have seen a rise in in situ technologies, and researchers now have the capability to obtain high-resolution measurements of $\delta^{18} \mathrm{O}_{\mathrm{H} 2 \mathrm{O}}$ and $\delta^{13} \mathrm{C}_{\text {DIC. }}$. As these technologies continue to extend to other nutrients (e.g., nitrate) and become more affordable, it will be important for watershed modelers to understand the limitations and applicability of the high-resolution data streams, which will require close collaboration with isotope geochemists. We foresee high utility for water quality model frameworks that use high-resolution isotope sensing to inform practical watershed management decisions.

Further, the cutting-edge work that has been conducted on $\delta^{18} \mathrm{OPO}_{\mathrm{PO}}$ DRP and PIP over the past decade and the lack of ambient tracers of $\mathrm{P}$ source fate and transport (Jarvie et al., 2014; Williams et al., 2016) suggest a need to assess the efficacy of $\delta^{18} \mathrm{O}_{\mathrm{PO} 4}$ in water quality modeling frameworks. Several challenges exist that will require interdisciplinary collaboration to recognize the full potential of the oxygen isotope signature of phosphate as a tool for informing water quality models. Regarding dissolved inorganic phosphate, a current barrier is the large sample volume needed to precipitate an adequate mass of $\mathrm{Ag}_{3} \mathrm{PO}_{4}$ for isotope analysis, given the low ambient DRP concentrations (McLaughlin et al., 2004; Young et al., 2009; Pistocchi et al., 2017). In addition, based on existing datasets, it is not clear that the approach may robustly distinguish between nonpoint pollution sources, which has led to suggestions of database expansion of $\mathrm{P}$ source characterization in freshwater ecosystems (Young et al., 2009; Davies et al., 2014). A third limitation is that most existing methods for soil and sediment extraction are not pool specific (see Haney et al., 2013, for the exception) and typically reflect adsorbed phosphate, dissolution of phosphate-bearing precipitates, and mineralized organic matter (Tamburini et al., 2014; Davies et al., 2014; Pistocchi et al., 2017). Despite these limitations, isotope measurement provides valuable information on biological processing of $\mathrm{P}$ that is not otherwise measurable with existing methods (Pistocchi et al., 2017). We foresee $\delta^{18} \mathrm{O}_{\mathrm{PO}}$ to hold great promise for numerical model advancement, and we foresee that concurrent advancement of water quality modeling technology with analytical techniques may lead to more robust management of $\mathrm{P}$ in fluvial landscapes.

\section{CONCLUSIONS}

While model uncertainty continues to be a major challenge facing scientists and engineers, stable isotopes are promising tools for improving in-stream nutrient fate and transport routines in water quality models. This is an exciting time for water quality modelers, as new data streams, such as stable isotopes, offer the promise of constraining model uncertainty. This review highlighted the ability of stable isotopes to (1) improve estimates of boundary conditions, (2) reduce model equifinality, and (3) elucidate model improvement needs by identifying deficiencies in perceptual or numerical model frameworks. As a final note, regarding 
the reduction of model equifinality, we highlight the importance for modelers to provide quantitative evidence of uncertainty reduction in future applications. This quantitative evidence is often missing in recent studies, given the emphasis of the studies on establishing new methodologies and showing their efficacy. This effort should be commended; nevertheless, future studies might report quantitative evidence to help researchers understand when the extra data stream and modeling effort are most useful and when they are not. We foresee that such quantitative evidence will also provide modelers with a metric to inform cost-benefit analyses associated with model data collection decisions.

\section{ACKNOWLEDGEMENTS}

We thank the University of Kentucky Department of Biosystems and Agricultural Engineering for partial funding of the graduate student while at the University of Kentucky. We gratefully acknowledge financial support of this research under National Science Foundation Award No. 163288, which provided partial support for the graduate student and corresponding author. This is Publication No. 17-05-074 of the Kentucky Agricultural Experiment Station and is published with the approval of the Director. This work is supported by the USDA National Institute of Food and Agriculture. Finally, we thank the three anonymous reviewers whose input and suggestions greatly improved the quality of the manuscript.

\section{REFERENCES}

Adiyanti, S., Eyre, B. D., Maher, D. T., Santos, I., Golsby-Smith, L., Mangion, P., \& Hipsey, M. R. (2016). Stable isotopes reduce parameter uncertainty of an estuarine carbon cycling model. Environ. Model. Softw., 79, 233-255. https://doi.org/10.1016/j.envsoft.2016.02.011

Angert, A., Weiner, T., Mazeh, S., \& Sternberg, M. (2012). Soil phosphate stable oxygen isotopes across rainfall and bedrock gradients. Environ. Sci. Tech., 46(4), 2156-2162. https://doi.org/10.1021/es203551s

Angradi, T. R. (1994). Trophic linkages in the lower Colorado River: Multiple stable isotope evidence. J. North American Benthol. Soc., 13(4), 479-495.

Aravena, R., \& Robertson, W. D. (1998). Use of multiple isotope tracers to evaluate denitrification in ground water: Study of nitrate from a large-flux septic system plume. Ground Water, 36(6), 975-982. https://doi.org/10.1111/j.17456584.1998.tb02104.x

Ashkenas, L. R., Johnson, S. L., Gregory, S. V., Tank, J. L., \& Wollheim, W. M. (2004). A stable isotope tracer study of nitrogen uptake and transformation in an old-growth forest stream. Ecol., 85(6), 1725-1739. https://doi.org/10.1890/03-0032

Baker, D. B., Johnson, L. T., Confesor, R. B., \& Crumrine, J. P. (2017). Vertical stratification of soil phosphorus as a concern for dissolved phosphorus runoff in the Lake Erie basin. J. Environ. Qual., 46(6), 1287-1295. https://doi.org/10.2134/jeq2016.09.0337

Bernot, M. J., \& Dodds, W. K. (2005). Nitrogen retention, removal, and saturation in lotic ecosystems. Ecosystems, 8(4), 442-453. https://doi.org/10.1007/s10021-003-0143-y

Beven, K. (2006). A manifesto for the equifinality thesis. J. Hydrol., 320(1), 18-36. https://doi.org/10.1016/j.jhydrol.2005.07.007

Beven, K., \& Binley, A. (1992). The future of distributed models: Model calibration and uncertainty prediction. Hydrol. Proc.,
6(3), 279-298. https://doi.org/10.1002/hyp.3360060305

Birgand, F., Skaggs, R. W., Chescheir, G. M., \& Gilliam, J. W. (2007). Nitrogen removal in streams of agricultural catchments: A literature review. Crit. Rev. Environ. Sci. Tech., 37(5), 381487. https://doi.org/10.1080/10643380600966426

Böhlke, J. K., Harvey, J. W., \& Voytek, M. A. (2004). Reach-scale isotope tracer experiment to quantify denitrification and related processes in a nitrate-rich stream, midcontinent United States. Limnol. Oceanogr., 49(3), 821-838. https://doi.org/10.4319/1o.2004.49.3.0821

Böhlke, J. K., Smith, R. L., \& Miller, D. N. (2006). Ammonium transport and reaction in contaminated groundwater: Application of isotope tracers and isotope fractionation studies. Water Resour. Res., 42(5), W05411. https://doi.org/10.1029/2005WR004349

Borah, D. K., \& Bera, M. (2003). Watershed-scale hydrologic and nonpoint-source pollution models: Review of mathematical bases. Trans. ASAE, 46(6), 1553-1566. https://doi.org/10.13031/2013.15644

Brandes, J. A., \& Devol, A. H. (2002). A global marine-fixed nitrogen isotopic budget: Implications for Holocene nitrogen cycling. Global Biogeochem. Cycles, 16(4), 1120. https://doi.org/10.1029/2001GB001856

Bremner, J. M., \& Keeney, D. R. (1966). Determination and isotope-ratio analysis of different forms of nitrogen in soils: 3 . Exchangeable ammonium, nitrate, and nitrite by extractiondistillation methods. SSSA J., 30(5), 577-582. https://doi.org/10.2136/sssaj1966.03615995003000050015x

Casciotti, K. L., Sigman, D. M., \& Ward, B. B. (2003). Linking diversity and stable isotope fractionation in ammonia-oxidizing bacteria. Geomicrobiol. J., 20(4), 335-353. https://doi.org/10.1080/01490450303895

Chang, C. C., Kendall, C., Silva, S. R., Battaglin, W. A., \& Campbell, D. H. (2002). Nitrate stable isotopes: Tools for determining nitrate sources among different land uses in the Mississippi River basin. Canadian J. Fisheries Aquatic Sci., 59(12), 1874-1885. https://doi.org/10.1139/f02-153

Chapra, S. C., Pelletier, G. J., \& Tao, H. (2008). QUAL2K: A modeling framework for simulating river and stream water quality, Vers. 2.11: Documentation and users manual. Medford, MA: Tufts University, Department of Civil and Environmental Engineering. Retrieved from Steven.Chapra@tufts.edu

Cifuentes, L. A., Fogel, M. L., Pennock, J. R., \& Sharp, J. H. (1989). Biogeochemical factors that influence the stable nitrogen isotope ratio of dissolved ammonium in the Delaware estuary. Geochim. Cosmochim. Acta, 53(10), 2713-2721. https://doi.org/10.1016/0016-7037(89)90142-7

Clément, J.-C., Holmes, R. M., Peterson, B. J., \& Pinay, G. (2003). Isotopic investigation of denitrification in a riparian ecosystem in western France. J. Appl. Ecol., 40(6), 1035-1048. https://doi.org/10.1111/j.1365-2664.2003.00854.x

Collins, A. L., Walling, D. E., \& Leeks, G. J. (1998). Use of composite fingerprints to determine the provenance of the contemporary suspended sediment load transported by rivers. Earth Surface Proc. Landforms, 23(1), 31-52.

https://doi.org/10.1002/(SICI)10969837(199801)23:1<31::AID-ESP816>3.0.CO;2-Z

Davies, C. L., Surridge, B. W., \& Gooddy, D. C. (2014). Phosphate oxygen isotopes within aquatic ecosystems: Global data synthesis and future research priorities. Sci. Total Environ., 496, 563-575. https://doi.org/10.1016/j.scitotenv.2014.07.057

Davis, C. M., \& Fox, J. F. (2009). Sediment fingerprinting: Review of the method and future improvements for allocating nonpointsource pollution. J. Environ. Eng., 135(7), 490-504. https://doi.org/10.1061/(ASCE)0733-9372(2009)135:7(490)

Dean, S., Freer, J., Beven, K., Wade, A. J., \& Butterfield, D. (2009). 
Uncertainty assessment of a process-based integrated catchment model of phosphorus. Stochastic Environ. Res. Risk Assess., 23(7), 991-1010. https://doi.org/10.1007/s00477-008-0273-z

Delwiche, C. C., \& Steyn, P. L. (1970). Nitrogen isotope fractionation in soils and microbial reactions. Environ. Sci. Tech., 4(11), 929-935. https://doi.org/10.1021/es60046a004

Di Toro, D. M. (2001). Sediment flux modeling (Vol. 116). New York, NY: Wiley-Interscience.

Doctor, D. H., Kendall, C., Sebestyen, S. D., Shanley, J. B., Ohte, N., \& Boyer, E. W. (2008). Carbon isotope fractionation of dissolved inorganic carbon (DIC) due to outgassing of carbon dioxide from a headwater stream. Hydrol. Proc., 22(14), 24102423. https://doi.org/10.1002/hyp.6833

Doi, H. (2009). Spatial patterns of autochthonous and allochthonous resources in aquatic food webs. Population Ecol., 51(1), 57-64. https://doi.org/10.1007/s10144-008-0127-z

Droppo, I. G., Lau, Y. L., \& Mitchell, C. (2001). The effect of depositional history on contaminated bed sediment stability. Sci. Total Environ., 266(1), 7-13. https://doi.org/10.1016/S00489697(00)00748-8

Droppo, I. G., Walling, D. E., \& Ongley, E. D. (2000). Influence of floc size, density, and porosity on sediment and contaminant transport. In M. Stone (Ed.) The role of erosion and sediment transport in nutrient and contaminant transfer (pp. 141-147). IAHS Publication No. 263. Wallingford, UK: IAHS.

Elsbury, K. E., Paytan, A., Ostrom, N. E., Kendall, C., Young, M. B., McLaughlin, K., ... Watson, S. (2009). Using oxygen isotopes of phosphate to trace phosphorus sources and cycling in Lake Erie. Environ. Sci. Tech., 43(9), 3108-3114. https://doi.org/10.1021/es8034126

England, L. E., \& Rosemond, A. D. (2004). Small reductions in forest cover weaken terrestrial-aquatic linkages in headwater streams. Freshwater Biol., 49(6), 721-734. https://doi.org/10.1111/j.1365-2427.2004.01219.x

Finlay, J. C. (2001). Stable-carbon-isotope ratios of river biota: Implications for energy flow in lotic food webs. Ecology, 82(4), 1052-1064. https://doi.org/10.2307/2679902

Fogel, M. L., \& Cifuentes, L. A. (1993). Isotope fractionation during primary production. In M. H. Engel \& S. A. Macko (Eds.), Organic geochemistry: Principles and applications (pp. 73-98). Boston, MA: Springer. https://doi.org/10.1007/978-14615-2890-6_3

Ford, W. I., \& Fox, J. F. (2014). Model of particulate organic carbon transport in an agriculturally impacted stream. Hydrol. Proc., 28(3), 662-675. https://doi.org/10.1002/hyp.9569

Ford, W. I., \& Fox, J. F. (2015). Isotope-based fluvial organic carbon (ISOFLOC) model: Model formulation, sensitivity, and evaluation. Water Resour. Res., 51(6), 4046-4064. https://doi.org/10.1002/2015WR016999

Ford, W. I., \& Fox, J. F. (2017). Stabilization of benthic algal biomass in a temperate stream draining agroecosystems. Water Res., 108, 432-443. https://doi.org/10.1016/j.watres.2016.11.026

Ford, W. I., Fox, J. F., \& Pollock, E. (2017). Reducing equifinality using isotopes in a process-based stream nitrogen model highlights the flux of algal nitrogen from agricultural streams. Water Resour. Res., 53(8), 6539-6561. https://doi.org/10.1002/2017WR020607

Ford, W. I., Fox, J. F., \& Rowe, H. (2015a). Impact of extreme hydrologic disturbance upon the sediment carbon quality in agriculturally impacted temperate streams. Ecohydrology, 8(3), 438-449. https://doi.org/10.1002/eco.1514

Ford, W. I., Fox, J. F., Pollock, E., Rowe, H., \& Chakraborty, S. (2015b). Testing assumptions for nitrogen transformation in a low-gradient agricultural stream. J. Hydrol., 527, 908-922. https://doi.org/10.1016/j.jhydrol.2015.05.062

Fox, J. F. (2009). Measurements of sediment transport processes in forested watersheds with surface coal mining disturbance using carbon and nitrogen isotopes. JAWRA, 45(5), 1273-1289. https://doi.org/10.1111/j.1752-1688.2009.00365.x

Fox, J. F., \& Ford, W. I. (2016). Impact of landscape disturbance on the quality of terrestrial sediment carbon in temperate streams. $J$. Hydrol., 540, 1030-1042. https://doi.org/10.1016/j.jhydrol.2016.07.016

Fox, J. F., \& Martin, D. K. (2014). Sediment fingerprinting for calibrating a soil erosion and sediment-yield model in mixed land-use watersheds. J. Hydrol. Eng., 20(6), C4014002. https://doi.org/10.1061/(ASCE)HE.1943-5584.0001011

Fox, J. F., \& Papanicolaou, A. N. (2007). The use of carbon and nitrogen isotopes to study watershed erosion processes. JAWRA, 43(4), 1047-1064. https://doi.org/10.1111/j.17521688.2007.00087.x

Fox, J. F., Davis, C. M., \& Martin, D. K. (2010). Sediment source assessment in a lowland watershed using nitrogen stable isotopes. JAWRA, 46(6), 1192-1204. https://doi.org/10.1111/j.1752-1688.2010.00485.x

Fox, J., Ford, W., Strom, K., Villarini, G., \& Meehan, M. (2014). Benthic control upon the morphology of transported fine sediments in a low-gradient stream. Hydrol. Proc., 28(11), 37763788. https://doi.org/10.1002/hyp.9928

Fukada, T., Hiscock, K. M., Dennis, P. F., \& Grischek, T. (2003). A dual-isotope approach to identify denitrification in groundwater at a river-bank infiltration site. Water Res., 37(13), 3070-3078. https://doi.org/10.1016/S0043-1354(03)00176-3

Galand, P. E., Yrjala, K., \& Conrad, R. (2010). Stable carbon isotope fractionation during methanogenesis in three boreal peatland ecosystems. Biogeosciences, 7(11), 3893-3900. https://doi.org/10.5194/bg-7-3893-2010

Gammons, C. H., Babcock, J. N., Parker, S. R., \& Poulson, S. R. (2011). Diel cycling and stable isotopes of dissolved oxygen, dissolved inorganic carbon, and nitrogenous species in a stream receiving treated municipal sewage. Chem. Geol., 283(1), 44-55. https://doi.org/10.1016/j.chemgeo.2010.07.006

Gong, Y., Shen, Z., Hong, Q., Liu, R., \& Liao, Q. (2011). Parameter uncertainty analysis in watershed total phosphorus modeling using the GLUE methodology. Agric. Ecosyst. Environ., 142(3), 246-255. https://doi.org/10.1016/j.agee.2011.05.015

Grey, J., Jones, R. I., \& Sleep, D. (2001). Seasonal changes in the importance of the source of organic matter to the diet of zooplankton in Loch Ness, as indicated by stable isotope analysis. Limnol. Oceanogr., 46(3), 505-513. https://doi.org/10.4319/lo.2001.46.3.0505

Guzman, J. A., Shirmohammadi, A., Sadeghi, A. M., Wang, X., Chu, M. L., Jha, M. K., ... Hernandez, J. E. (2015). Uncertainty considerations in calibration and validation of hydrologic and water quality models. Trans. ASABE, 58(6), 1745-1762. https://doi.org/10.13031/trans.58.10710

Haas, M. B., Guse, B., Pfannerstill, M., \& Fohrer, N. (2016). A joined multi-metric calibration of river discharge and nitrate loads with different performance measures. J. Hydrol., 536, 534545. https://doi.org/10.1016/j.jhydrol.2016.03.001

Han, F., \& Zheng, Y. (2016). Multiple-response Bayesian calibration of watershed water quality models with significant input and model structure errors. Adv. Water Resour., 88, 109123. https://doi.org/10.1016/j.advwatres.2015.12.007

Haney, R. L., White, M. J., Arnold, J. G., Haney, E. B., \& Harmel, R. D. (2013). Re-defining and quantifying inorganic phosphate pools in the Soil and Water Assessment Tool. J. Soil Sci.

Environ. Mgmt., 4(8), 155-162. https://doi.org/10.5897/JSSEM12.048

Herman, J. D., Reed, P. M., \& Wagener, T. (2013). Time-varying sensitivity analysis clarifies the effects of watershed model formulation on model behavior. Water Resour. Res., 49(3), 
1400-1414. https://doi.org/10.1002/wrcr.20124

Hong, Y.-S., Rifkin, E., \& Bouwer, E. J. (2014). Modeling mercury distribution in the Sarasota Bay ecosystem using SERAFM and stable isotope ratios of nitrogen $\left(\delta^{15} \mathrm{~N}\right)$ in biota. Environ. Eng. Sci., 31(3), 135-147. https://doi.org/10.1089/ees.2013.0293

Hood, E., Williams, M. W., \& McKnight, D. M. (2005). Sources of dissolved organic matter (DOM) in a Rocky Mountain stream using chemical fractionation and stable isotopes.

Biogeochemistry, 74(2), 231-255.

https://doi.org/10.1007/s10533-004-4322-5

Hope, D., Billett, M. F., \& Cresser, M. S. (1994). A review of the export of carbon in river water: Fluxes and processes. Environ. Pollut., 84(3), 301-324. https://doi.org/10.1016/02697491(94)90142-2

Hotchkiss, E. R., \& Hall, R. O. (2015). Whole-stream ${ }^{13} \mathrm{C}$ tracer addition reveal distinct fates of newly fixed carbon. Ecology, 96(2), 403-416. http://dx.doi.org/10.1890/14-0631.1.sm

Husic, A., Fox, J., Agouridis, C., Currens, J., Ford, W., \& Taylor, C. (2017a). Sediment carbon fate in phreatic karst (Part 1): Conceptual model development. J. Hydrol., 549, 179-193. https://doi.org/10.1016/j.jhydrol.2017.03.052

Husic, A., Fox, J., Ford, W., Agouridis, C., Currens, J., \& Taylor, C. (2017b). Sediment carbon fate in phreatic karst (Part 2): Numerical model development and application. J. Hydrol., 549, 208-219. https://doi.org/10.1016/j.jhydrol.2017.03.059

Imberger, S. J., Cook, P. L., Grace, M. R., \& Thompson, R. M. (2014). Tracing carbon sources in small urbanising streams: Catchment-scale stormwater drainage overwhelms the effects of reach-scale riparian vegetation. Freshwater Biol., 59(1), 168186. https://doi.org/10.1111/fwb.12256

Jacinthe, P. A., Lal, R., \& Owens, L. B. (2009). Application of stable isotope analysis to quantify the retention of eroded carbon in grass filters at the North Appalachian experimental watersheds. Geoderma, 148(3), 405-412. https://doi.org/10.1016/j.geoderma.2008.11.013

Jarvie, H. P., Sharpley, A. N., Brahana, V., Simmons, T., Price, A., Neal, C., ... Haggard, B. E. (2014). Phosphorus retention and remobilization along hydrological pathways in karst terrain. Environ. Sci. Tech., 48(9), 4860-4868. https://doi.org/10.1021/es405585b

Jin, X., Xu, C.-Y., Zhang, Q., \& Singh, V. P. (2010). Parameter and modeling uncertainty simulated by GLUE and a formal Bayesian method for a conceptual hydrological model. $J$. Hydrol., 383(3), 147-155. https://doi.org/10.1016/j.jhydrol.2009.12.028

Joshi, S. R., Kukkadapu, R. K., Burdige, D. J., Bowden, M. E., Sparks, D. L., \& Jaisi, D. P. (2015). Organic matter remineralization predominates phosphorus cycling in the midbay sediments in the Chesapeake Bay. Environ. Sci. Tech., 49(10), 5887-5896. https://doi.org/10.1021/es5059617

Kao, S. J., \& Liu, K. K. (2000). Stable carbon and nitrogen isotope systematics in a human-disturbed watershed (Lanyang-Hsi) in Taiwan and the estimation of biogenic particulate organic carbon and nitrogen fluxes. Global Biogeochem. Cycles, 14(1), 189-198. https://doi.org/10.1029/1999GB900079

Kaown, D., Koh, D. C., Mayer, B., \& Lee, K. K. (2009). Identification of nitrate and sulfate sources in groundwater using dual stable isotope approaches for an agricultural area with different land use (Chuncheon, mid-eastern Korea). Agric. Ecosyst. Environ., 132(3), 223-231. https://doi.org/10.1016/j.agee.2009.04.004

Karamanos, R. E., \& Rennie, D. A. (1978). Nitrogen isotope fractionation during ammonium exchange reactions with soil clay. Canadian J. Soil Sci., 58(1), 53-60. https://doi.org/10.4141/cjss78-005

Kendall, C., \& Caldwell, E. A. (1998). Fundamentals of isotope geochemistry. In Isotope tracers in catchment hydrology (pp. 51-86). Cambridge, MA: Elsevier.

Kendall, C., Elliott, E. M., \& Wankel, S. D. (2007). Tracing anthropogenic inputs of nitrogen to ecosystems. In Stable isotopes in ecology and environmental science (2nd ed., pp. 375449). Oxford, UK: Blackwell. https://doi.org/10.1002/9780470691854.ch12

Kendall, C., Silva, S. R., \& Kelly, V. J. (2001). Carbon and nitrogen isotopic compositions of particulate organic matter in four large river systems across the United States. Hydrol. Proc., 15(7), 1301-1346. https://doi.org/10.1002/hyp.216

Kendall, C., Young, M. B., \& Silva, S. R. (2010). Applications of stable isotopes for regional to national-scale water quality and environmental monitoring programs. In J. B. West, G. J. Bowen, T. E. Dawson, \& K. P. Tu (Eds.), Isoscapes (pp. 89-111). Dordrecht, The Netherlands: Springer. https://doi.org/10.1007/978-90-481-3354-3_5

Koiter, A. J., Owens, P. N., Petticrew, E. L., \& Lobb, D. A. (2013). The behavioural characteristics of sediment properties and their implications for sediment fingerprinting as an approach for identifying sediment sources in river basins. Earth-Sci. Rev., 125, 24-42. https://doi.org/10.1016/j.earscirev.2013.05.009

Komor, S. C. (1997). Boron contents and isotopic compositions of hog manure, selected fertilizers, and water in Minnestoa. $J$. Environ. Qual., 26(5), 1212-1222. https://doi.org/10.2134/jeq1997.00472425002600050004x

Kritzberg, E. S., Cole, J. J., Pace, M. L., Graneli, W., \& Bade, D. L. (2004). Autochthonous versus allochthonous carbon sources of bacteria: Results from whole-lake ${ }^{13} \mathrm{C}$ addition experiments. Limnol. Oceanogr., 49(2), 588-596. https://doi.org/10.4319/lo.2004.49.2.0588

Lane, C. S., Lyon, D. R., \& Ziegler, S. E. (2013). Cycling of two carbon substrates of contrasting lability by heterotrophic biofilms across a nutrient gradient of headwater streams. Aquatic Sci., 75(2), 235-250. https://doi.org/10.1007/s00027-012-0269-0

Lau, D. C., Leung, K. M., \& Dudgeon, D. (2009). What does stable isotope analysis reveal about trophic relationships and the relative importance of allochthonous and autochthonous resources in tropical streams? A synthetic study from Hong Kong. Freshwater Biol., 54(1), 127-141. https://doi.org/10.1111/j.1365-2427.2008.02099.x

Lehmann, M. F., Bernasconi, S. M., Barbieri, A., Simona, M., \& McKenzie, J. A. (2004). Interannual variation of the isotopic composition of sedimenting organic carbon and nitrogen in Lake Lugano: A long-term sediment trap study. Limnol. Oceanogr., 49(3), 839-849. https://doi.org/10.4319/lo.2004.49.3.0839

Lu, L., Cheng, H., Pu, X., Wang, J., Cheng, Q., \& Liu, X. (2016). Identifying organic matter sources using isotopic ratios in a watershed impacted by intensive agricultural activities in northeast China. Agric. Ecosyst. Environ., 222, 48-59. https://doi.org/10.1016/j.agee.2015.12.033

Maggi, F., \& Riley, W. J. (2009). Transient competitive complexation in biological kinetic isotope fractionation explains nonsteady isotopic effects: Theory and application to denitrification in soils. J. Geophys. Res. Biogeosci., 114(G4). https://doi.org/10.1029/2008JG000878

Mariotti, A., Germon, J. C., Hubert, P., Kaiser, P., Letolle, R., Tardieux, A., \& Tardieux, P. (1981). Experimental determination of nitrogen kinetic isotope fractionation: Some principles; illustration for the denitrification and nitrification processes. Plant Soil, 62(3), 413-430. https://doi.org/10.1007/bf02374138

McDonnell, J. J., \& Beven, K. (2014). Debates - The future of hydrological sciences: A (common) path forward? A call to action aimed at understanding velocities, celerities and residence time distributions of the headwater hydrograph. Water Resour. 
Res., 50(6), 5342-5350. https://doi.org/10.1002/2013WR015141

McGuire, K., \& McDonnell, J. (2007). Stable isotope tracers in watershed hydrology. In Stable isotopes in ecology and environmental science (pp. 334-374). Oxford, UK: Blackwell. https://doi.org/10.1002/9780470691854.ch11

McKinney, C. R., McCrea, J. M., Epstein, S., Allen, H. A., \& Urey, H. C. (1950). Improvements in mass spectrometers for the measurement of small differences in isotope abundance ratios. Rev. Sci. Instruments, 21(8), 724-730. https://doi.org/10.1063/1.1745698

McLaughlin, K., Silva, S., Kendall, C., Stuart-Williams, H., \& Paytan, A. (2004). A precise method for the analysis of $\delta^{18} \mathrm{O}$ of dissolved inorganic phosphate in seawater. Limnol. Oceanogr. Methods, 2(7), 202-212. https://doi.org/10.4319/lom.2004.2.202

Mook, W. G. (2006). Introduction to isotope hydrology: Stable and radioactive isotopes of hydrogen, carbon, and oxygen. Boca Raton, FL: CRC Press.

Moriasi, D. N., Arnold, J. G., Van Liew, M. W., Bingner, R. L., Harmel, R. D., \& Veith, T. L. (2007). Model evaluation guidelines for systematic quantification of accuracy in watershed simulations. Trans. ASABE, 50(3), 885-900. https://doi.org/10.13031/2013.23153

Muleta, M. K. (2012). Uncertainty analysis and calibration of SWMM using a formal Bayesian methodology. Proc. World Environ. and Water Resources Congress (pp. 562-568). Reston, VA: ASCE. https://doi.org/10.1061/9780784412312.060

Needoba, J. A., Waser, N. A., Harrison, P. J., \& Calvert, S. E. (2003). Nitrogen isotope fractionation in 12 species of marine phytoplankton during growth on nitrate. Marine Ecol. Prog. Series, 255, 81-91. https://doi.org/10.3354/meps255081

Palmer, S. M., Hope, D., Billett, M. F., Dawson, J. J., \& Bryant, C. L. (2001). Sources of organic and inorganic carbon in a headwater stream: Evidence from carbon isotope studies. Biogeochemistry, 52(3), 321-338. https://doi.org/10.1023/a:1006447706565

Papanicolaou, A. N., Fox, J. F., \& Marshall, J. (2003). Soil fingerprinting in the Palouse basin, USA, using stable carbon and nitrogen isotopes. Intl. J. Sediment Res., 18(2), 278-284.

Pardo, L. H., Kendall, C., Pett-Ridge, J., \& Chang, C. C. (2004). Evaluating the source of streamwater nitrate using $\delta^{15} \mathrm{~N}$ and $\delta^{18} \mathrm{O}$ in nitrate in two watersheds in New Hampshire, USA. Hydrol. Proc., 18(14), 2699-2712. https://doi.org/10.1002/hyp.5576

Park, R. A., Clough, J. S., \& Wellman, M. C. (2008). AQUATOX: Modeling environmental fate and ecological effects in aquatic ecosystems. Ecol. Model., 213(1), 1-15. https://doi.org/10.1016/j.ecolmodel.2008.01.015

Peterson, B. J., Wollheim, W. M., Mulholland, P. J., Webster, J. R., Meyer, J. L., Tank, J. L., ... Morrall, D. D. (2001). Control of nitrogen export from watersheds by headwater streams. Science, 292(5514), 86-90. https://doi.org/10.1126/science.1056874

Phillips, J. M., Russell, M. A., \& Walling, D. E. (2000). Timeintegrated sampling of fluvial suspended sediment: A simple methodology for small catchments. Hydrol. Proc., 14(14), 25892602. https://doi.org/10.1002/10991085(20001015)14:14<2589::AID-HYP94>3.0.CO;2-D

Pistocchi, C., Tamburini, F., Gruau, G., Ferhi, A., Trevisan, D., \& Dorioz, J.-M. (2017). Tracing the sources and cycling of phosphorus in river sediments using oxygen isotopes: Methodological adaptations and first results from a case study in France. Water Res., 111, 346-356. https://doi.org/10.1016/j.watres.2016.12.038

Raymond, P. A., McClelland, J. W., Holmes, R. M., Zhulidov, A. V., Mull, K., Peterson, B. J., ... \& Gurtovaya, T. Y. (2007). Flux and age of dissolved organic carbon exported to the Arctic Ocean: A carbon isotopic study of the five largest arctic rivers.
Global Biogeochem. Cycles, 21(4), GB4011. https://doi.org/10.1029/2007GB002934

Reusser, D. E., Buytaert, W., \& Zehe, E. (2011). Temporal dynamics of model parameter sensitivity for computationally expensive models with the Fourier amplitude sensitivity test. Water Resour. Res., 47(7), W07551. https://doi.org/10.1029/2010WR009947

Robson, B. J. (2014). When do aquatic systems models provide useful predictions, what is changing, and what is next? Environ. Model. Softw., 61, 287-296. https://doi.org/10.1016/j.envsoft.2014.01.009

Rode, M., Arhonditsis, G., Balin, D., Kebede, T., Krysanova, V., van Griensven, A., \& van der Zee, S. E. (2010). New challenges in integrated water quality modeling. Hydrol. Proc., 24(24), 3447-3461. https://doi.org/10.1002/hyp.7766

Rode, M., Suhr, U., \& Wriedt, G. (2007). Multi-objective calibration of a river water quality model: Information content of calibration data. Ecol. Model., 204(1), 129-142. https://doi.org/10.1016/j.ecolmodel.2006.12.037

Rosenfeld, J. S., \& Roff, J. C. (1992). Examination of the carbon base in southern Ontario streams using stable isotopes. J. North American Benthol. Soc., 11(1), 1-10. https://doi.org/10.2307/1467877

Rounick, J. S., \& Winterbourn, M. J. (1986). Stable carbon isotopes and carbon flow in ecosystems. BioScience, 36(3), 171-177. https://doi.org/10.2307/1310304

Rounick, J. S., Winterbourn, M. J., \& Lyon, G. L. (1982). Differential utilization of allochthonous and autochthonous inputs by aquatic invertebrates in some New Zealand streams: A stable carbon isotope study. Oikos, 39(2), 191-198.

Russo, J., \& Fox, J. (2012). The role of the surface fine-grained laminae in low-gradient streams: A model approach. Geomorphology, 171-172, 127-138. https://doi.org/10.1016/j.geomorph.2012.05.012

Sarà, G., Scilipoti, D., Mazzola, A., \& Modica, A. (2004). Effects of fish farming waste to sedimentary and particulate organic matter in a southern Mediterranean area (Gulf of Castellammare, Sicily): A multiple stable isotope study $\left(\delta^{13} \mathrm{C}\right.$ and $\left.\delta^{15} \mathrm{~N}\right)$. Aquaculture, 234(1), 199-213.

Schiff, S. L., Aravena, R., Trumbore, S. E., \& Dillon, P. J. (1990). Dissolved organic carbon cycling in forested watersheds: A carbon isotope approach. Water Resour. Res., 26(12), 29492957.

Sebestyen, S. D., Shanley, J. B., Boyer, E. W., Kendall, C., \& Doctor, D. H. (2014). Coupled hydrological and biogeochemical processes controlling variability of nitrogen species in streamflow during autumn in an upland forest. Water Resour. Res., 50(2), 1569-1591. https://doi.org/10.1002/2013WR013670

Sebilo, M., Billen, G., Grably, M., \& Mariotti, A. (2003). Isotopic composition of nitrate-nitrogen as a marker of riparian and benthic denitrification at the scale of the whole Seine River system. Biogeochemistry, 63(1), 35-51. https://doi.org/10.1023/a:1023362923881

Seibert, J., \& McDonnell, J. J. (2002). On the dialog between experimentalist and modeler in catchment hydrology: Use of soft data for multicriteria model calibration. Water Resour. Res., 38(11), 1241. https://doi.org/10.1029/2001WR000978

Seiler, R. L. (2005). Combined use of ${ }^{15} \mathrm{~N}$ and ${ }^{18} \mathrm{O}$ of nitrate and ${ }^{11} \mathrm{~B}$ to evaluate nitrate contamination in groundwater. Appl. Geochem., 20(9), 1626-1636. https://doi.org/10.1016/j.apgeochem.2005.04.007

Sharp, Z. (2007). Principles of stable isotope geochemistry. Upper Saddle River, NJ: Pearson Education.

Shen, Z. Y., Chen, L., \& Chen, T. (2012). Analysis of parameter uncertainty in hydrological and sediment modeling using GLUE method: A case study of SWAT model applied to Three Gorges 
Reservoir region, China. Hydrol. Earth Syst. Sci., 16(1), 121132. https://doi.org/10.5194/hess-16-121-2012

Sigman, D. M., Granger, J., DiFiore, P. J., Lehmann, M. M., Ho, R., Cane, G., \& van Geen, A. (2005). Coupled nitrogen and oxygen isotope measurements of nitrate along the eastern North Pacific margin. Global Biogeochem. Cycles, 19(4), GB4022. https://doi.org/10.1029/2005GB002458

Soulsby, C., Birkel, C., Geris, J., Dick, J., Tunaley, C., \& Tetzlaff, D. (2015). Stream water age distributions controlled by storage dynamics and nonlinear hydrologic connectivity: Modeling with high-resolution isotope data. Water Resour. Res., 51(9), 77597776. https://doi.org/10.1002/2015WR017888

Tamburini, F., Pfahler, V., Bunemann, E. K., Guelland, K., Bernasconi, S. M., \& Frossard, E. (2012). Oxygen isotopes unravel the role of microorganisms in phosphate cycling in soils. Environ. Sci. Tech., 46(11), 5956-5962. https://doi.org/10.1021/es300311h

Tamburini, F., Pfahler, V., von Sperber, C., Frossard, E., \& Bernasconi, S. M. (2014). Oxygen isotopes for unraveling phosphorus transformations in the soil-plant system: A review. SSSA J., 78(1), 38-46. https://doi.org/10.2136/sssaj2013.05.0186dgs

Thornton, S. F., \& McManus, J. (1994). Application of organic carbon and nitrogen stable isotope and $\mathrm{C} / \mathrm{N}$ ratios as source indicators of organic matter provenance in estuarine systems: Evidence from the Tay estuary, Scotland. Estuarine Coastal Shelf Sci., 38(3), 219-233. https://doi.org/10.1006/ecss.1994.1015

Throckmorton, H. M., Heikoop, J. M., Newman, B. D., Altmann, G. L., Conrad, M. S., Muss, J. D., ... Wilson, C. J. (2015). Pathways and transformations of dissolved methane and dissolved inorganic carbon in Arctic tundra watersheds: Evidence from analysis of stable isotopes. Global Biogeochem. Cycles, 29(11), 1893-1910. https://doi.org/10.1002/2014GB005044

Tobias, C., \& Böhlke, J. K. (2011). Biological and geochemical controls on diel dissolved inorganic carbon cycling in a loworder agricultural stream: Implications for reach scales and beyond. Chem. Geol., 283(1), 18-30.

Van Engeland, T., De Kluijver, A., Soetaert, K., Meysman, F. J., \& Middelburg, J. J. (2012). Isotope data improve the predictive capabilities of a marine biogeochemical model. Biogeosci. Discuss., 9453-9486. https://doi.org/10.5194/bgd-9-9453-2012

Van Griensven, A., \& Bauwens, W. (2003). Multiobjective autocalibration for semidistributed water quality models. Water Resour. Res., 39(12), 1348. https://doi.org/10.1029/2003WR002284

Velinsky, D. J., Pennock, J. R., Sharp, J. H., Cifuentes, L. A., \& Fogel, M. L. (1989). Determination of the isotopic composition of ammonium-nitrogen at the natural abundance level from estuarine waters. Marine Chem., 26(4), 351-361. https://doi.org/10.1016/0304-4203(89)90040-6

Walling, D. E., Collins, A. L., Jones, P. A., Leeks, G. J., \& Old, G. (2006). Establishing fine-grained sediment budgets for the Pang and Lambourn LOCAR catchments, U.K. J. Hydrol., 330(1), 126-141. https://doi.org/10.1016/j.jhydrol.2006.04.015

Wang, J., Li, X., Lu, L., \& Fang, F. (2013). Parameter sensitivity analysis of crop growth models based on the extended Fourier amplitude sensitivity test method. Environ. Model. Softw., 48, 171-182. https://doi.org/10.1016/j.envsoft.2013.06.007

Wankel, S. D., Kendall, C., Francis, C. A., \& Paytan, A. (2006). Nitrogen sources and cycling in the San Francisco Bay estuary:
A nitrate dual-isotopic composition approach. Limnol. Oceanogr., 51(4), 1654-1664.

https://doi.org/10.4319/1o.2006.51.4.1654

Webster, C. R., \& Heymsfield, A. J. (2003). Water isotope ratios $\mathrm{D} / \mathrm{H},{ }^{18} \mathrm{O} /{ }^{16} \mathrm{O},{ }^{17} \mathrm{O} /{ }^{16} \mathrm{O}$ in and out of clouds map dehydration pathways. Science, 302(5651), 1742-1745. https://doi.org/10.1126/science.1089496

Wellen, C., Kamran-Disfani, A.-R., \& Arhonditsis, G. B. (2015). Evaluation of the current state of distributed watershed nutrient water quality modeling. Environ. Sci. Tech., 49(6), 3278-3290. https://doi.org/10.1021/es5049557

Widory, D., Kloppmann, W., Chery, L., Bonnin, J., Rochdi, H., \& Guinamant, J.-L. (2004). Nitrate in groundwater: An isotopic multi-tracer approach. J. Contam. Hydrol., 72(1), 165-188. https://doi.org/10.1016/j.jconhyd.2003.10.010

Williams, M. R., King, K. W., Ford, W., Buda, A. R., \& Kennedy, C. D. (2016). Effect of tillage on macropore flow and phosphorus transport to tile drains. Water Resour. Res., 52(4), 2868-2882. https://doi.org/10.1002/2015WR017650

Windhorst, D., Kraft, P., Timbe, E., Frede, H. G., \& Breuer, L. (2014). Stable water isotope tracing through hydrological models for disentangling runoff generation processes at the hillslope scale. Hydrol. Earth Syst. Sci., 18, 4113-4127. https://doi.org/10.5194/hess-18-4113-2014

Withers, P. J., \& Jarvie, H. P. (2008). Delivery and cycling of phosphorus in rivers: A review. Sci. Total Environ., 400(1), 379395. https://doi.org/10.1016/j.scitotenv.2008.08.002

Wool, T. A., Ambrose, R. B., Martin, J. L., Comer, E. A., \& Tech, T. (2006). Water quality analysis simulation program (WASP): User's manual (ver. 6). Washington, DC: U.S. Environmental Protection Agency.

Xue, D., Botte, J., De Baets, B., Accoe, F., Nestler, A., Taylor, P., ... Boeckx, P. (2009). Present limitations and future prospects of stable isotope methods for nitrate source identification in surface- and groundwater. Water Res., 43(5), 1159-1170. https://doi.org/10.1016/j.watres.2008.12.048

Xue, D., De Baets, B., Van Cleemput, O., Hennessy, C., Berglund, M., \& Boeckx, P. (2014). Classification of nitrate polluting activities through clustering of isotope mixing model outputs. $J$. Environ. Qual., 42(5), 1486-1497. https://doi.org/10.2134/jeq2012.0456

Yamanaka, T., \& Ma, W. (2017). Runoff prediction in a poorly gauged basin using isotope-calibrated models. J. Hydrol., 544, 567-574. https://doi.org/10.1016/j.jhydrol.2016.12.005

Yen, H., Wang, X., Fontane, D. G., Harmel, R. D., \& Arabi, M. (2014). A framework for propagation of uncertainty contributed by parameterization, input data, model structure, and calibration/validation data in watershed modeling. Environ. Model. Softw., 54, 211-221. https://doi.org/10.1016/j.envsoft.2014.01.004

Young, M. B., McLaughlin, K., Kendall, C., Stringfellow, W., Rollog, M., Elsbury, K., ... Paytan, A. (2009). Characterizing the oxygen isotopic composition of phosphate sources to aquatic ecosystems. Environ. Sci. Tech., 43(14), 5190-5196. https://doi.org/10.1021/es900337q

Zah, R., Burgherr, P., Bernasconi, S. M., \& Uehlinger, U. (2001). Stable isotope analysis of macroinvertebrates and their food sources in a glacier stream. Freshwater Biol., 46(7), 871-882. https://doi.org/10.1046/j.1365-2427.2001.00720.x 